\title{
The curious case of the camelthorn: competition, coexistence and nest-site limitation in a multispecies mutualism
}

Article

Accepted Version

Campbell, H., Fellowes, M. D.E. and Cook, J. (2015) The curious case of the camelthorn: competition, coexistence and nest-site limitation in a multispecies mutualism. American Naturalist, 186 (6). E172-E181. ISSN 0003-0147 doi: https://doi.org/10.1086/683462 Available at https://centaur.reading.ac.uk/45901/

It is advisable to refer to the publisher's version if you intend to cite from the work. See Guidance on citing.

Published version at: http://www.jstor.org/stable/10.1086/683462

To link to this article DOI: http://dx.doi.org/10.1086/683462

Publisher: University of Chicago Press

All outputs in CentAUR are protected by Intellectual Property Rights law, including copyright law. Copyright and IPR is retained by the creators or other copyright holders. Terms and conditions for use of this material are defined in the End User Agreement.

www.reading.ac.uk/centaur 
Central Archive at the University of Reading

Reading's research outputs online 
The curious case of the camelthorn: competition, coexistence and nest-site limitation in a multispecies mutualism

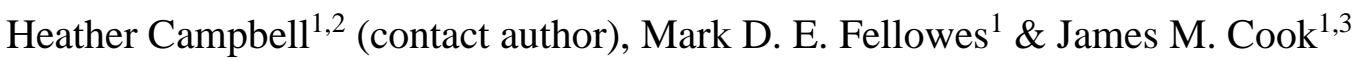

${ }^{1}$ School of Biological Sciences, University of Reading, Reading, RG6 6AS, United Kingdom

${ }^{2}$ Department of Zoology and Entomology, University of Pretoria, Pretoria 0002, South

Africa

${ }^{3}$ Hawkesbury Institute for the Environment, University of Western Sydney, Sydney, Australia

Key words: ant-plant interactions, coexistence, domatia, myrmecophytes, mutualism, nestsite limitation

Elements for expanded online edition

Online appendix A - Expanded methods and results

(methods; randomisation results, tables A1-4; diagrammatic representation of multiple species co-occupancy on $V$. erioloba trees, figure A1; results for species pairs Spearman's rank correlation, table A5; review of myrmecophyte plant and domatia occupancy studies, table A6)

Data deposited in the Dryad Digital Repository: doi:10.5061/dryad.s9f7c

Type of article: Natural history miscellany 


\begin{abstract}
Myrmecophyte plants house ants in domatia in exchange for protection from herbivores. Antmyrmecophyte mutualisms exhibit two general patterns due to competition between ants for plant occupancy: i) domatia nest-sites are a limiting resource and ii) each individual plant hosts one ant species at a time. However, individual camelthorn trees (Vachellia erioloba) typically host two to four ant species simultaneously, often coexisting in adjacent domatia on the same branch. Such fine-grain spatial coexistence brings into question the conventional wisdom on ant-myrmecophyte mutualisms. Camelthorn ants appear not to be nest-site limited, despite low abundance of suitable domatia, and have random distributions of nestsites within and across trees. These patterns suggest a lack of competition between ants for domatia and contrast strongly with other ant-myrmecophyte systems. Comparison of this unusual case with others suggests that spatial scale is crucial to coexistence or competitive exclusion involving multiple ant species. Furthermore, coexistence may be facilitated when co-occurring ant species diverge strongly on at least one niche axis. Our conclusions provide recommendations for future ant-myrmecophyte research, particularly in utilising multispecies systems to further our understanding of mutualism biology.
\end{abstract}




\section{Introduction}

Ant-plant interactions are used as model systems to test hypotheses about ecological networks (Lange and Del-Claro 2014), mutualism dynamics (Heil and McKey 2003) and the effects of global change on interacting species (Mayer et al. 2014). Interactions vary from facultative to obligate, and range from mutualism to parasitism. Plants benefit from ants via services including seed dispersal (Gallegos et al. 2014), pollination (de Vega et al. 2009), nutrient enrichment (Wagner and Fleur Nicklen 2010) and protection against herbivory (Trager et al. 2010). In exchange myrmecophilic plants provide food to ants, a process that is taxonomically widespread (Weber and Keeler 2013). Food may take the form of extrafloral nectar, honeydew via sap-feeding insects and food bodies rich in lipids and proteins (Heil and McKey 2003). In addition, myrmecophytic plants also provide housing for ants within domatia. These are modified plant structures such as thorns, stems and leaves that form hollow chambers specifically for ant nest-sites (Davidson and McKey 1993). Myrmecophytes are restricted to the tropics (Heil and McKey 2003) with well-studied taxa including Cecropia (Dejean et al. 2012), Macaranga (Nomura et al. 2011), Tococa (Michelangeli 2003) and, perhaps most famously, Vachellia (formerly Acacia, Janzen 1974; Palmer et al. 2008).

Most studies support the common view that there is intense inter and intra-specific competition between ant colonies for sole occupancy of myrmecophytes (Davidson et al. 1989; Kautz et al. 2012; Palmer 2004; Webber et al. 2007), and that plant-ants are extremely aggressive and territorial (for example, Palmer et al. 2000). Ant colonies may compete for food resources provided by the plant, but also for domatia in which to nest (Fonseca 1999). We define three occupancy categories for ants on a given myrmecophyte plant at a given time: a) single colony occupancy (SCO); b) single species (multiple colony) occupancy (SSO) and multiple species co-occupancy (MSC). An individual plant usually shows SSO 
(which may be SCO, but is often not tested), although the plant species may associate with more than one ant species (Davidson et al. 1989; Gaume and McKey 1999; Palmer et al. 2003). An individual plant may show MSC as a sapling (Djiéto-Lordon et al. 2005; Longino 1989) or sequentially throughout its lifetime, because ant colonisation is moderated by species dominance hierarchies (Palmer et al. 2000). Outside of myrmecophyte systems, nestsite limitation influences ant species richness, and therefore possibly coexistence, for cavitynesting ants, although the effect is variable across arboreal (Philpott and Foster 2005) and leaf-litter assemblages (Byrne 1994). In myrmecophytes, ant colony size is limited by the size and availability of domatia for nesting-sites (Campbell et al. 2013a; Fonseca 1993; Fonseca 1999), but the effect on species coexistence is unknown.

Competition is a key element in structuring ant communities (see review by Cerdá et al. 2013). Interspecific competition leads to non-random structure in communities, because species with similar niches co-occur less often than expected by chance (Diamond 1975), as demonstrated across multiple taxa (Gotelli and McCabe 2002). In arboreal ant assemblages dominant species defend "absolute territories" - discrete spatial units extending beyond the location of individual food or nest resources. This leads to a patchy distribution of ant species across the forest canopy, known as an ant mosaic (Dejean et al. 2007; Jackson 1984; Room 1971; Room 1975). However, outside forest ecosystems the arboreal patterns of ant species coexistence and competition are less well documented. In savannas, where trees are widely spaced, there is no continuous canopy layer in which ant mosaics can form (Dejean et al. 2007). The dominant trees of African savannas are acacias, many of which are myrmecophytes that possess swollen-thorn domatia inhabited by ants (Dharani 2006). Coexistence of ant species on neighbouring myrmecophyte acacias is thought to result from dominance hierarchies and competitive trade-offs (Palmer et al. 2010; Palmer et al. 2000; 
Stanton et al. 2005). However, coexistence at a finer spatial scale, across or within branches of the same tree, has seldom been studied. This is largely because the few intensively studied systems (for example, Gaume and McKey 1999; Palmer et al. 2010) do not show long-term MSC. MSC on myrmecophytes or semi-myrmecophytes has been documented occasionally (Gaume et al. 2005b; Moog et al. 2002; Raine et al. 2004; Rico-Gray and Thien 1989a; RicoGray and Thien 1989b), but these unusual examples contrast with the many myrmecophytes that exhibit competitive exclusion and SSO.

In this study we investigated the camelthorn tree, Vachellia erioloba (fig. 1A), a southern African myrmecophyte with swollen-thorn domatia (fig. 1B and C) inhabited by four ant species; an unidentified Crematogaster species, Cataulacus intrudens, an unidentified Tapinoma species and Tetraponera ambigua. A previous study revealed $41 \%$ MSC of $V$. erioloba trees, with some evidence of species sorting through nest-site selection based on domatia characteristics (Campbell et al. 2013a). Given this surprising finding, we undertook comprehensive sampling specifically to quantify MSC in V. erioloba and to test for evidence of nest-site limitation and competition. We also test if nest-site selection differs between ant species based on microhabitat characteristics related to the location of domatia on the tree.

Our findings bring into question two widely held assumptions; i) myrmecophyte ants utilising domatia are nest-site limited; and ii) ant species compete for sole occupancy of individual plants. To establish if the unusual patterns in the camelthorn system are unique, we then review published patterns of plant and domatia occupancy to test for nest-site limitation and MSC in other myrmecophyte systems. 
Methods

Study site and sampling

Field work was conducted in savanna at Kuzikus Wildlife Reserve $\left(23^{\circ} 13 ' \mathrm{~S}, 18^{\circ} 24^{\prime} \mathrm{E}\right.$, elevation 1340m) in Namibia (for full site description see Campbell et al. 2013b). Surveys were completed in April, September and October 2011 for ant occupants within swollenthorns on camelthorn trees, Vachellia erioloba (E. Mey) P.J.H. Hurter. Ants defend V. erioloba trees from insect herbivores (Campbell et al. 2013b) and low intensity sampling in an earlier study suggested MSC of individual trees (Campbell et al. 2013a). For each of 20 haphazardly selected trees we surveyed 8-13 branches, except for one tree with only four branches accessible. Using secateurs, branches were removed and all thorns opened to examine the contents. We also recorded microhabitat data on: branch height from ground (to nearest $0.1 \mathrm{~m}$ ); branch cardinal direction (bearing in ${ }^{\circ}$ ); thorn status (swollen or non-swollen); thorn age (new, young, old or dead); and thorn position on branch (surveying from the tip inwards towards the trunk, 1 being the most distal thorn sampled). For each thorn we recorded ant species identity and an estimate of the number of ants at different life stages (workers, brood, alates and queens).

\section{Analysis}

To test for associations between ant species at the branch level we performed Spearman's rank correlations on the presence of species on the same branch. To assess the role of competition in structuring within-tree patterns of ant species co-occurrence we assembled a presence-absence matrix for each of the 20 trees and then performed Monte Carlo randomisation tests on each matrix. We used three co-occurrence indices (CHECKER, COMBO and C-score) under two null models (fixed-fixed and fixed equiprobable, for details see Appendix A). We calculated the Standardised Effect Size (SES) to allow comparison 
between matrices (Gotelli and McCabe 2002). To test the null hypothesis that the mean SES measured did not differ from zero we used a one-sample Wilcoxon test to compare across matrices. We performed six tests (three indices x two null models) and therefore applied a Bonferroni correction.

To assess whether the distribution of nest-sites across a tree was influenced by microhabitat we tested for correlations of ant species with thorn and branch variables. In tests of branch variables we analysed only species presence / absence on a branch. We tested ant species identity against branch height and cardinal direction using ANOVA and made multiple post hoc comparisons using Tukey Honest Significant Differences Tests (Crawley 2005). Thorn variables and ant species identity were only tested for occupied thorns (i.e. domatia that were currently in use as nest-sites). Although ants may be defend empty neighbouring thorns prior to colony expansion it was impossible to assign species identity to an unoccupied thorn so this is not accounted for in our analysis. Due to differential branch growth across trees, thorn position along a branch does not directly predict thorn age, so, for all occupied thorns, we tested separately if species identity was correlated with thorn position or thorn age using Fisher's exact tests (Crawley 2005). Thorn position was converted to a categorical variable, assigned as: distal (thorns 1-8); medial (thorns 9-15); or proximal (thorns 16+).

We assessed species co-occurrence with respect to microhabitat characteristics of branch height and cardinal direction (following the procedure of Belinchón et al. 2012). We constructed 16 presence-absence matrices representing branch cardinal direction (North: 316$45^{\circ}$, East: $46-135^{\circ}$, South: $136-225^{\circ}$ and West: $226-315^{\circ}$ ) combined with one of four branch height categories (Low: 0-1.50m; Medium Low: 1.51-2.0m; Medium High: 2.01-2.5m and 
High: $2.51 \mathrm{~m}+$ ). These analyses followed the same procedure described for within-tree matrices (methods A1). To test the effects of branch height and direction on species interactions, we performed ANOVA on all co-occurrence indices generated from these matrices.

Co-occurrence randomisation analyses (further details in Appendix A) were conducted in EcoSim (Gotelli and Entsminger 2009). All other statistical analyses were performed in R (R Core Development Team 2012).

\section{Literature review}

To establish if the unusual patterns in the camelthorn system are unique, we reviewed published patterns of plant and domatia occupancy to test for nest-site limitation and MSC in other systems. We examined 34 primary studies relating to 49 plant species (table A6) for examples of MSC. We included studies featured in three meta-analyses of ant-plant mutualisms (Chamberlain and Holland 2009; Rosumek et al. 2009; Trager et al. 2010) as a representative subset of studies likely to have suitable data. We also added data from several studies published after these meta-analyses and for cases where inadequate data were provided in the original cited references.

Results

Multiple species co-occupancy (MSC) on camelthorn trees

We collected data on 3448 thorns from 197 branches across $20 \mathrm{~V}$. erioloba trees (Campbell et al. 2015), confirming that $V$. erioloba domatia were occupied by four ant species; an unidentified Crematogaster species, Cataulacus intrudens, an unidentified Tapinoma species and Tetraponera ambigua (hereafter referred to by genus). The smallest, Tapinoma, was the 
most abundant, accounting for $77 \%$ of all individual ants surveyed (fig. 2), followed by Crematogaster (13\%), Cataulacus (8\%), and then Tetraponera (2\%). Tapinoma was also the most prevalent, found on 19 of 20 trees. Despite the numerical dominance of Tapinoma, it occupied a similar proportion (41\%) of nest-sites to Crematogaster (42\%, see fig. 2), while the other two species occupied far fewer (Cataulacus 14\%; Tetraponera 3\%).

Most trees (16/20) were co-occupied by two or three ant species and $3 / 20$ by all four. The only tree with a single ant species was occupied by Crematogaster. Although MSC was common within trees, at the branch level the figure fell to $27 \%$, while $50 \%$ of branches were occupied by a single species (figure A1). On branches, Cataulacus and Tapinoma were positively associated (Spearman correlation test: $\mathrm{r}_{\mathrm{S}}=0.17, \mathrm{~S}=1051634, P<0.05$ ), but there were no other significant associations between species pairs (table A5).

\section{Nest-site limitation and interspecific competition}

Only $31 \%(n=1052)$ of thorns were suitable as nest-sites, because ants were not found inside soft, new growth thorns or non-swollen thorns. Hereafter the term domatia refers only to swollen and hardened thorns suitable as nest-sites. Only 37\% of domatia were occupied by nesting ants. Nest-site density varied significantly between species, with Crematogaster occupying the most domatia per branch and Cataulacus the least (fig. 3).

Within-trees we found little evidence of positive or negative associations between ant species. Only one tree showed a non-random distribution of species with an observed C-score of 17.33 that was significantly larger $(P=0.001)$ than the mean simulated C-score of 7.95 . The SES was 3.104, indicating segregation of ant species on that tree (table A1). Our meta- 
analysis across matrices for all trees showed that the mean SES did not differ significantly from zero for any of the indices under either null model (table A3).

\section{Microhabitat preferences}

We found no evidence that different ant species used domatia in different locations on trees, with regard to branch height (ANOVA, $F_{3,211}=1.16, P=0.33$ ), branch cardinal direction (ANOVA, $F_{3,211}=2.048, P=0.11$ ) or thorn position along a branch (Fisher's exact test, $P=0.14$ ). Nor did we detect evidence of non-random patterns for nest-sites grouped by microhabitat characteristics (table A2). This was confirmed by meta-analyses of cooccurrence indices that showed species distributions are not influenced by branch height or direction (table A4). However, Cataulacus and Tapinoma were associated with old thorns and Crematogaster and Tetraponera with young thorns (Fisher's exact test, $P<0.01$ ).

\section{Discussion}

Ant community ecology has focused heavily on the role of competition in structuring ant assemblages (Cerdá et al. 2013; Parr and Gibb 2010; Parr et al. 2005) but this has been less frequently applied to ants on myrmecophilic or myrmecophytic plants (however, see review by Palmer et al. 2003). Given the abundance of studies on ant-plant mutualisms the data is most likely already available for studies of competition within these systems and would significantly advance our understanding of the dynamics of ant-ant interactions as well as mutualism biology. Whilst it is thought that ants compete for host plants (Stanton et al. 2005) or that domatia nest-sites are limiting (Longino 1989), there has been little experimental proof to find evidence of competition in these systems, or to identify the mechanisms for this (Palmer et al. 2003). 
There is no evidence that ants on V. erioloba are nest-site limited, because only $38 \%$ of domatia are occupied. This rate of domatia occupancy does not seem atypical of ant-plant systems in general (see table A6). In the studies we reviewed domatia occupancy ranged from 42-64 \% (Maschwitz et al. 1994; Moog et al. 2002), although for one species variation was high (0-100\%) between individual plants (Dyer and Letourneau 1999). Zanthoxylum myriacanthum was the only MSC myrmecophyte with rate of domatia occupancy reported (table 1; table A6), which at $42 \%$ is very similar to domatia occupancy on camelthorn trees. However, it is striking that domatia occupancy was not reported in $93 \%$ of primary studies even though this information was very likely collected. Overall, the few existing studies do not support the notion that individual domatia are a limiting resource, but this does not rule out availability of whole plants as limiting for ant colonies.

At the whole plant level, overall occupancy of myrmecophytes was between 41-100\% in the reviewed studies (table A6) and $100 \%$ on V. erioloba. Focusing on MSC myrmecophytes, the rate of plant occupancy was slightly higher, ranging from $62-100 \%$. The high rate of plant occupancy relative to domatia occupancy implies that availability of individual plants may often be the key to ant colony success. This also explains why competition between foundresses and young colonies for possession of a host plant is so intense (Stanton et al. 2005). Whereas once a colony has secured a plant then individual domatia availability may exceed colony requirements.

The apparently random distribution of species within trees provides further evidence that V. erioloba ants are not competing for domatia. This pattern is surprising and contrasts with spatial patterns on a Neotropical acacia exhibiting MSC (Raine et al. 2004). We propose that on $V$. erioloba fine scale within-tree coexistence and lack of strong spatial structure 
reflect an absence of competition for individual domatia. Moreover, each ant species tends to choose different subsets of nests (e.g. species sorting according to thorn age and size, see Campbell et al. 2013a), as well as exhibiting different patterns of nest-site distribution and density. Species coexistence on V. erioloba may also be facilitated by the differing life history strategies of each ant species (Campbell et al. 2013a), as has been demonstrated in acacia-Pseudomyrmex interactions (Kautz et al. 2012). Establishing colony boundaries between conspecific ants co-occupying a tree is the next step in understanding spatial patterns of domatia-inhabiting ants on V. erioloba. However, in a pilot study to test colony boundaries we did not observe any intra- or interspecific aggression between $V$. erioloba ants. Future work could compensate for the lack of behavioural assay data by utilising genetic microsatellite and cuticular hydrocarbons data instead (Kautz et al. 2012).

At the species level, most plants (30/49 species, table A6) associate with multiple ant species and this is very likely an underestimate. Most myrmecophytes associate with a guild of ants, via either a) an individual plant associating with multiple ant species over its lifetime, or b) different individual plants in a population associating with different ant species. Ant partners may also vary across geographic scales (Longino 1989) and some myrmecophytes lose their mutualist ants altogether (Moraes and Vasconcelos 2009). This highlights the important issues of scale and specificity in studying species interactions (Thompson 2005). A 1:1 level of partner species matching may often be recorded on individual plants, but additional ant partners may be added by looking across plants in a population, or across populations through the plants geographic range.

It was typically difficult to establish species occupancy states (unknown for 10/49 species, table A6) and particularly MSC from the literature as authors were not always 
explicit about this. Ultimately, we found only four examples (table 1) of MSC (Gaume et al. 2005a; Moog et al. 2002; Rico-Gray and Thien 1989a) and only one of these described the pattern of ant species coexistence within individual host plants (Raine et al. 2004). These four cases appear extremely divergent, and occur on different continents, in contrasting habitats and incorporate a diversity of plant types and domatia structures (table 1). In our study, 95\% of individual camelthorn showed MSC. Ant species were the same as a previous study (Campbell et al. 2013a), suggesting temporal stability of species assemblages, at least over short periods of time. This level of simultaneous coexistence is highly unusual and, to our knowledge, has not previously been recorded for an African ant-acacia. It contrasts directly with other African acacias, notably, the intensely studied $V$. drepanolobium system where trees are occupied not only by a single species (SSO) but usually also by a single colony of ants (SCO) (Palmer et al. 2000; Stanton et al. 2005). This raises the questions, do mutualism dynamics differ when a plant has one or more ant partners? And what drives transitions between SCO, SSO and MSC states?

In systems where guilds of ants inhabit different individual host plants within a population it is frequently discovered that not all ants are mutualists (Edwards et al. 2010; Gaume and McKey 1999; Itioka et al. 2000) and that mutualists differ in their effectiveness (Frederickson 2005; Young et al. 1997). Although increased competition can actually encourage co-operation of multiple mutualist partners (Adam 2010). Nonetheless, it is critical to understand the nature of the relationship between ants and their host plant since parasites may be more likely to co-occupy host plants (Kautz et al. 2012). A great deal of literature is directed towards analysing the costs and benefits of interactions and how systems may allow for the existence of "cheaters" (for example, see Clement et al. 2008; Edwards et al. 2006; Kautz et al. 2012). The key difference in myrmecophytes exhibiting MSC is the scale at 
which coexistence occurs i.e. tree or branch level rather than population level. However, both empirical and theoretical frameworks designed to tackle population level questions of ant species coexistence (as reviewed by Palmer et al. 2003) are equally applicable to this finer spatial scale. The main difficulty in performing experimental work in MSC cases is logistical. Manipulations on mature plants would be complex and the best approach would be to perform exclusions and additions of different combinations of ant species using seedlings until plants reach maturity. This would be problematic on a large, slow-growing tree such as V. erioloba, but better suited to a pioneer species such as the MSC myrmecophyte, $Z$. myriacanthum (Moog et al. 2002). This would also allow for experimentation over a longer time scale, and facilitate cost-benefit analysis over the lifetime of a plant or ant colony that may potentially reveal differing insights to a short-term study (e.g. short term, Palmer et al. 2000; vs long term, Stanton and Palmer 2011).

Multispecies mutualisms may arise as evolutionary "by-products" (Fayle et al. 2011) when ants defend trees as part of their normal foraging activity. Multiple simultaneous ant partners may provide more (greater defence) or wider (defence against diverse foes) benefits to an individual host plant. In this context tree size or density may influence the costs and benefits of MSC for myrmecophytes. Large, isolated desert or savanna trees, might benefit from a suite of ant occupants in order to be effectively defended. Smaller plants or those found in dense forests with many potential opportunistic ant mutualists may fare well with one resident ant colony. MSC might alternatively arise from a lack of host sanctions resulting in the presence of multiple, opportunistic species. For example, an inability to limit access to domatia leads to the presence of parasites on the rattan ant-palm Korthalsia furtadoana (Edwards et al. 2010). 
Environmental stress can determine levels of species diversity in ant assemblages. Habitat productivity may also play a role in diversity within mutualisms via species coexistence mechanisms, for example, competitively dominant ants occupy faster-growing host plants and more productive habitats (Palmer 2003). Subsequently, should we expect MSC systems to be found in more or less stressful environments? Multiple limiting resources can increase niche dimensionality, leading to higher levels of diversity. Conversely a decline in the number and heterogeneity of limiting resources causes fewer trade-off opportunities, decreased niche dimensionality and fewer co-existing species (Harpole and Tilman 2007). If niche dimensionality does influence myrmecophyte-inhabiting ants, we predict that that more stressful environments with multiple limiting resources will contain a greater number of MSC plants and a higher diversity of ant partners. Although data is limited the anecdotal evidence somewhat supports this prediction; V. erioloba is a savanna/desert species in a high temperature and aridity region and mangrove orchids with MSC are found in very high salinity environments (Rico-Gray and Thien 1989b). To test stress-diversity relationships in ant-myrmecophyte systems, MSC mutualisms could be compared across environmental (stress/productivity) gradients, or subjected to local resource availability manipulations. A factorial experiment of this kind could not only tease out the relative importance of different resources on species, but changes observed in number of ant occupants following restriction or addition of resources would indicate a role for niche dimensionality in ant-myrmecophyte interactions.

Two widely-held assumptions about ant-myrmecophyte mutualisms are challenged by our findings on V. erioloba: 1) ant-plants are inhabited by a single species at a time and, therefore, ant coexistence only occurs across a population of plants or a single plant's lifetime; 2) plant-ants are nest-site limited on their host myrmecophyte (Fonseca 1993; Yu et 
al. 2004). We found other examples of MSC in the literature (Moog et al. 2002; Raine et al. 2004; Rico-Gray and Thien 1989b), but domatia occupancy rates are sorely missing from most published studies. Despite this, the few studies reporting patterns suggest no saturation of domatia (Dyer and Letourneau 1999; Maschwitz et al. 1994; Moog et al. 2002). Competition-colonization trade-offs (Stanton et al. 2002) and dispersal-fecundity trade-offs (Yu et al. 2004) have both been highlighted as likely mechanisms for species co-existence on myrmecophytes, but most research has focused on a few popular study species. The approaches taken with these species could easily be expanded to MSC myrmecophytes to aid our understanding of competition and coexistence in ant/plant systems. The study of multispecies systems has been highlighted as vital to progress our understanding of mutualisms (Fayle et al. 2011; Palmer et al. 2003). We hope that the opportunity presented to study ant communities on V. erioloba, as well as the other MSC systems highlighted here, provides a starting point for a better understanding of multispecies mutualism dynamics.

\section{Acknowledgements}

This research was funded through a Biotechnology and Biological Sciences Research Council studentship to H. Campbell. The funder's had no role in the study design, data collection and analysis, decision to publish, or preparation of the manuscript. The full dataset is deposited in the Dryad Digital Repository (doi:10.5061/dryad.s9f7c, Campbell et al. 2015). We thank staff at Kuzikus Wildlife Reserve for logistical support and I. Townsend, N. Kay and J. Reinhard for assistance with data collection. We also thank G. Stone for discussion of fieldwork plans, Nigel Raine for helpful suggestions on the $\mathrm{PhD}$ chapter that forms the basis of the manuscript and two anonymous referees for providing thoughtful and constructive comments on the manuscript. 


\section{Online appendix A - Expanded methods and results}

\section{Methods}

Many studies of coexistence use ants as a model system and utilise null model analyses to examine species co-occurrence patterns (Albrecht and Gotelli 2001; Gotelli and Ellison 2002; Sanders et al. 2007). A study of myrmecophytes and their associated ant species used a Monte Carlo randomisation and cluster analysis to reveal a highly structured community (Fonseca and Ganade 1996). Here we employ randomisation procedures to a smaller spatial scale to assess within-tree patterns of species co-occurrence and evidence of competition between plant-ants sharing access to nest resources on a myrmecophyte. A study of lichen distributions used co-occurrence indices as community metrics in a modelling approach (Belinchón et al. 2012). We employ the same principles in our methodology to assess microhabitat variables (branch height and direction) in relation to ant species nest-site distributions on V. erioloba camelthorn trees.

\section{Methods for testing within-tree species co-occurrence patterns}

We constructed 20 presence-absence matrices to assess ant species co-occurrence within individual trees. Each matrix represented a single, isolated $V$. erioloba tree, with ant species as rows ( $n=4$ species) and branches on the trees as columns ( $n=4$ to 12 branches). A species was scored as present if it had one or more nests on the branch.

We used three different indices to quantify patterns of nest site co-occurrence of ant species occupying V. erioloba trees; CHECKER, COMBO and C-score. CHECKER is the number of species pairs that never co-occur and therefore form a checkerboard distribution within the matrix. If this rule exists in an assemblage, then more species pairs should form 
checkerboard distributions than expected by chance (Gotelli and McCabe 2002). COMBO is the number of species combinations within an assemblage and may reveal the presence of forbidden species combinations. The C-score is the most widely used index of species cooccurrence (Sanders et al. 2007) as it has greater statistical power than the other indices (Gotelli 2000; Gotelli and McCabe 2002). This index is also a measure of "checkerboardness", but is less restrictive than CHECKER, as it calculates the degree of coexistence between species pairs rather than only counting completely segregated pairs (Gotelli 2000; Gotelli and McCabe 2002; Stone and Roberts 1990). The indices CHECKER and $\mathrm{COMBO}$ are more sensitive than the $\mathrm{C}$-score, which is not only less restrictive but also less prone to false positives (Gotelli 2000). Generally, if a community is structured by competition the observed assemblage should have more species forming a checkerboard distribution, less species combinations and a higher C-score than in a random community (Diamond 1975; Gotelli 2000), although other mechanisms can affect community structure and therefore the interpretation of indices (for a comprehensive review of null model testing in ecology see, Gotelli and Ulrich 2012; Ulrich and Gotelli 2013).

We used two null models to randomise the observed matrices and create simulated matrices. The fixed-fixed model preserves the row and column totals of the observed matrix. This means that the random community has the same number of species in each sample unit (column total), in this case branches, and each species occurs at the same frequency (row total). This model maintains the differences between the sites and species in the matrix, and for this reason has been suggested as appropriate for analysis of island species lists (Sanders et al. 2007). Isolated trees can be considered as islands of biodiversity and assemble in a similar way (Gove et al. 2009), so we consider this an appropriate model for analysing community patterns on individual trees $V$. erioloba trees in a savannah. 
The second, fixed-equiprobable model allows random variation in the total number of species found on each branch but maintains the same frequency of species within the overall matrix. This model treats all the branches on an individual tree as being equally suitable as nest sites for each of the species that are recorded on that tree. It is considered suitable for testing co-occurrence patterns at a local spatial scale (Sanders et al. 2007). The fixedequiprobable model has been recommended for comparison of standardised sampling procedures, such as baiting or pitfall trapping, in a homogenous habitat (Gotelli 2000). We utilise the fixed-equiprobable model in our analyses because the spatial scale is local (at the tree level). Additionally, it allows any number of species to co-occur on a single branch, which reflected our field observations of nest-site distributions.

To enable us to make comparisons across matrices, we calculated the standardised effect size (SES) for each matrix as follows; $\left(\mathrm{I}_{\mathrm{obs}}-\mathrm{I}_{\text {sim }}\right) / \mathrm{S}_{\text {sim }}$ where $\mathrm{I}_{\mathrm{obs}}$ is the observed value for the index, $\mathrm{I}_{\text {sim }}$ is the mean value of the index based on 5,000 null randomisation matrices and $\mathrm{S}_{\text {sim }}$ is the standard deviation of the index based on 5,000 null randomisation matrices (Gotelli and McCabe 2002). A one-sample Wilcoxon test was used to test the null hypothesis that the mean SES measured for the 20 presence-absence matrices did not differ from zero. We performed six tests (three indices using two null models) and applied a Bonferroni correction for multiple tests $(P<0.05 / 6)$. Co-occurrence analyses and Wilcoxon tests were conducted using EcoSim (Gotelli and Entsminger 2009) and R (R Core Development Team 2012), respectively.

\section{Methods for testing ant species microhabitat preference}

We constructed 16 presence-absence matrices to test if different ant species nest-sites are associated with different microhabitat characteristics. Each presence-absence matrix 
represented one of the four cardinal directions (North, East, South and West) combined with one of four height categories (Low: 0-1.50m; Medium Low: 1.51-2.0m; Medium High: 2.012.5m and High: $2.51 \mathrm{~m}+$ ). In a matrix, each row represented an ant species and each column represented a different branch that had been sampled. The branches (columns) within a matrix can be drawn from data for different individual trees and were included in a particular matrix based only on their shared microhabitat characteristics. The analyses performed on microhabitat matrices followed the same procedures as for the within-tree matrices. Three cooccurrence indices (CHECKER, C-score and COMBO) were generated under two null models (fixed-fixed and fixed equiprobable) and the standardised effect size (SES) was calculated for each microhabitat matrix. A one-sample Wilcoxon test was used to test the null hypothesis that the mean SES measured for the 16 microhabitat presence-absence matrices did not differ from zero. We performed six such tests (three indices using two null models) and applied a Bonferroni correction for multiple tests $(P<0.05 / 6)$.

The co-occurrence indices can be considered as community attributes and used in a modelling approach (Belinchón et al. 2012). To evaluate the effects of branch height and aspect on species interactions, we performed ANOVA on all co-occurrence indices. Beginning with the maximal model, we implemented stepwise model simplification to find the minimal adequate model for each index. Co-occurrence analyses were conducted in EcoSim (Gotelli and Entsminger 2009) and Wilcoxon tests and ANOVA were conducted in R (R Core Development Team 2012). 
Table A1 Randomisation results for 20 matrices of within-tree species co-occurrence patterns

\begin{tabular}{|c|c|c|c|c|c|c|c|c|c|c|c|c|}
\hline & \multicolumn{4}{|c|}{ C-score } & \multicolumn{4}{|c|}{ CHECKER } & \multicolumn{4}{|c|}{ COMBO } \\
\hline $\begin{array}{l}\text { Tree } \\
\text { fe model }\end{array}$ & $\mathrm{I}_{\mathrm{obs}}$ & $\mathrm{I}_{\text {sim }}$ & $P$ & SES & $\mathrm{I}_{\mathrm{obs}}$ & $\mathrm{I}_{\mathrm{sim}}$ & $P$ & SES & $\mathrm{I}_{\mathrm{obs}}$ & $\mathrm{I}_{\mathrm{sim}}$ & $P$ & SES \\
\hline 73 & 0 & 4.3 & 1.0 & -0.8 & 0 & 0 & 1.0 & 0.0 & 3 & 3.4 & 1.0 & -0.8 \\
\hline 76 & $\sim$ & & & & $\sim$ & & & & $\sim$ & & & \\
\hline 89 & 8 & 7.2 & 0.6 & 0.2 & 0 & 0.2 & 1.0 & -0.4 & 4 & 3.8 & 0.8 & 0.5 \\
\hline 90 & 6.7 & 6.8 & 0.6 & -0.1 & 0 & 0.4 & 1.0 & -0.7 & 7 & 6.1 & 0.3 & 1.2 \\
\hline 96 & 0 & 2.9 & 1.0 & -0.8 & 0 & 0.4 & 1.0 & -0.8 & 3 & 3.0 & 1.0 & 0.0 \\
\hline 215 & 4 & 8.2 & 0.9 & -1.4 & 0 & 0.0 & 1.0 & 0.0 & 6 & 6.3 & 0.9 & -0.5 \\
\hline 216 & 12 & 7.5 & 0.1 & 1.7 & 1 & 0.4 & 0.3 & 1.1 & 5 & 6.1 & 1.0 & -1.6 \\
\hline 217 & 17.3 & 7.9 & 0.0 & 3.1 & 1 & 0.3 & 0.3 & 1.3 & 5 & 6.0 & 1.0 & -1.5 \\
\hline 218 & 7 & 7.3 & 0.6 & -0.1 & 1 & 0.8 & 0.6 & 0.2 & 8 & 8.2 & 0.8 & -0.2 \\
\hline 219 & 5.8 & 5.7 & 0.5 & 0.1 & 2 & 1.8 & 0.6 & 0.2 & 8 & 7.2 & 0.3 & 1.1 \\
\hline 220 & 2 & 2.7 & 0.8 & -0.5 & 0 & 0.9 & 1.0 & -1.3 & 5 & 4.7 & 0.8 & 0.6 \\
\hline 227 & 5 & 3.6 & 0.2 & 0.8 & 1 & 0.3 & 0.3 & 1.3 & 5 & 5.3 & 0.9 & -0.5 \\
\hline 230 & 8 & 4.0 & 0.3 & 1.3 & 0 & 0.0 & 1.0 & -0.1 & 4 & 3.8 & 0.8 & 0.5 \\
\hline 231 & $\sim$ & & & & $\sim$ & & & & $\sim$ & & & \\
\hline 247 & 2 & 3.2 & 0.9 & -0.6 & 0 & 0.4 & 1.0 & -0.7 & 4 & 3.5 & 0.5 & 0.9 \\
\hline 248 & 1 & 1.6 & 0.9 & -1.4 & 3 & 4.4 & 1.0 & -1.3 & 5 & 4.9 & 0.8 & 0.1 \\
\hline 251 & 1 & 0.8 & 0.8 & 0.6 & 1 & 0.7 & 0.7 & 0.6 & 3 & 2.7 & 0.7 & 0.6 \\
\hline 252 & 1 & 2.3 & 0.9 & -0.9 & 0 & 0.8 & 1.0 & -1.1 & 5 & 4.4 & 0.4 & 1.2 \\
\hline 253 & 0.3 & 3.5 & 1.0 & -1.9 & 0 & 0.2 & 1.0 & -0.5 & 5 & 5.3 & 0.9 & -0.4 \\
\hline 254 & 6 & 4.3 & 0.5 & 0.6 & 0 & 0.0 & 1.0 & 0.0 & 4 & 3.9 & 0.9 & 0.4 \\
\hline ff model & & & & & & & & & & & & \\
\hline 73 & $\sim$ & & & & $\sim$ & & & & $\sim$ & & & \\
\hline 76 & $\sim$ & & & & $\sim$ & & & & $\sim$ & & & \\
\hline 89 & 8 & 8.0 & 1.0 & 0.0 & 0 & 0.0 & 1.0 & 0.0 & 4 & 4.0 & 1.0 & 0.0 \\
\hline 90 & 6.7 & 7.1 & 1.0 & -1.0 & 0 & 0.4 & 1.0 & -0.9 & 7 & 6.1 & 0.3 & 1.2 \\
\hline 96 & $\sim$ & & & & $\sim$ & & & & $\sim$ & & & \\
\hline 215 & 4 & 4.2 & 1.0 & -1.2 & 0 & 0.0 & 1.0 & 0.0 & 6 & 6.0 & 1.0 & 0.0 \\
\hline 216 & 12 & 10.5 & 0.1 & 2.5 & 1 & 0.8 & 0.7 & 0.3 & 5 & 6.1 & 1.0 & -1.6 \\
\hline 217 & 17.3 & 16.4 & 0.2 & 1.2 & 1 & 1.3 & 1.0 & -0.7 & 5 & 4.7 & 0.7 & 0.7 \\
\hline 218 & 7 & 6.9 & 0.4 & 0.2 & 1 & 0.9 & 0.7 & 0.1 & 8 & 8.4 & 0.9 & -0.4 \\
\hline 219 & 5.8 & 6.1 & 0.9 & -0.8 & 2 & 1.8 & 0.7 & 0.3 & 8 & 7.4 & 0.4 & 1.0 \\
\hline 220 & 2 & 2.0 & 1.0 & 0.0 & 0 & 0.0 & 1.0 & 0.0 & 5 & 5.0 & 1.0 & 0.0 \\
\hline 227 & 5 & 4.7 & 0.2 & 0.8 & 1 & 0.7 & 0.7 & 0.6 & 5 & 5.5 & 0.9 & -0.7 \\
\hline 230 & 8 & 8.0 & 1.0 & 0.0 & 0 & 0.0 & 1.0 & 0.0 & 4 & 4.0 & 1.0 & 0.0 \\
\hline 231 & $\sim$ & & & & $\sim$ & & & & $\sim$ & & & \\
\hline 247 & 2 & 2.0 & 1.0 & 0.0 & 0 & 0.0 & 1.0 & 0.0 & 4 & 4.0 & 1.0 & 0.0 \\
\hline 248 & 1 & 1.1 & 1.0 & -0.8 & 3 & 3.0 & 1.0 & 0.0 & 5 & 4.6 & 0.6 & 0.8 \\
\hline 251 & 1 & 1.0 & 1.0 & 0.0 & 1 & 1.0 & 1.0 & 0.0 & 3 & 3.0 & 1.0 & 0.0 \\
\hline 252 & 1 & 1.0 & 1.0 & 0.0 & 0 & 0.0 & 1.0 & 0.0 & 5 & 5.0 & 1.0 & 0.0 \\
\hline 253 & 0.3 & 0.3 & 1.0 & 0.0 & 0 & 0.0 & 1.0 & 0.0 & 5 & 5.0 & 1.0 & 0.0 \\
\hline 254 & 6 & 6.0 & 1.0 & 0.0 & 0 & 0.0 & 1.0 & 0.0 & 4 & 4.0 & 1.0 & 0.0 \\
\hline
\end{tabular}

Note: Local scale co-occurrence patterns on 20 individual $V$. erioloba trees at Kuzikus Wildlife Reserve, Namibia as measured by three co-occurrence indices for coexisting ant species. The presence-absence matrices analysed represent one of 20 different individual trees, with columns as sites (branches) and rows as species. Two null models were used for the analyses, fixed-equiprobable (fe model) maintains row sums but allows column totals to vary and fixed-fixed (ff model) maintains all row and column totals. $\mathrm{C}$-score is the $\mathrm{C}$-score calculated from the observed assemblages, CHECKER is the number of species forming a checkerboard distribution in the observed assemblages and $\mathrm{COMBO}$ is the number of species combinations in the observed assemblages. $\mathrm{I}_{\mathrm{obs}}$ is the observed value for the index and $\mathrm{I}_{\text {sim }}$ is the mean value of the index based on 5,000 null randomisation matrices. The SES is calculated from $\left(\mathrm{I}_{\mathrm{obs}}-\mathrm{I}_{\text {sim }}\right) / \mathrm{S}_{\text {sim }}$ where $\mathrm{S}_{\text {sim }}$ is the standard deviation of the index based on 5,000 null randomisation matrices. An SES value greater than 2 indicates segregation of 
species and an SES of less than -2 indicates significant species aggregation. Significant $P$ and SES values are highlighted yellow in bold type.

Table A2 Randomisation results for 16 matrices representing different microhabitat characteristics

\begin{tabular}{|c|c|c|c|c|c|c|c|c|c|c|c|c|c|}
\hline \multirow{2}{*}{ Direction } & \multirow[b]{2}{*}{ Height } & \multicolumn{4}{|c|}{ C-score } & \multicolumn{4}{|c|}{ CHECKER } & \multicolumn{4}{|c|}{ COMBO } \\
\hline & & $\mathrm{I}_{\mathrm{obs}}$ & $I_{\text {sim }}$ & $P$ & SES & $\mathrm{I}_{\mathrm{obs}}$ & $\mathrm{I}_{\mathrm{sim}}$ & $P$ & SES & $\mathrm{I}_{\mathrm{obs}}$ & $\mathrm{I}_{\text {sim }}$ & $P$ & SES \\
\hline \multicolumn{14}{|l|}{ fe model } \\
\hline \multirow[t]{4}{*}{ North } & Low & 6.2 & 5.0 & 0.2 & 0.9 & 4 & 3.7 & 0.6 & 0.3 & 6 & 6.1 & 0.8 & -0.2 \\
\hline & MedLow & 4.3 & 6.2 & 0.9 & -0.9 & 1 & 1.2 & 0.8 & -0.3 & 6 & 5.3 & 0.4 & 1.1 \\
\hline & MedHigh & 1.7 & 2.8 & 0.7 & -0.6 & 0 & 0.8 & 1.0 & -1.3 & 5 & 4.4 & 0.4 & 1.2 \\
\hline & High & 4.5 & 2.9 & 0.05 & 1.7 & 5 & 3.6 & 0.2 & 1.3 & 5 & 5.6 & 1.0 & -1.0 \\
\hline \multirow[t]{4}{*}{ East } & Low & 7 & 7.1 & 0.5 & 0.0 & 2 & 1.6 & 0.6 & 0.4 & 7 & 7.8 & 0.9 & -1.0 \\
\hline & MedLow & 17.7 & 14.9 & 0.2 & 0.8 & 2 & 0.8 & 0.2 & 1.6 & 10 & 9.1 & 0.3 & 1.2 \\
\hline & MedHigh & 2 & 3.3 & 0.9 & -0.8 & 0 & 1.0 & 1.0 & -1.4 & 5 & 4.9 & 0.9 & 0.4 \\
\hline & High & 13.3 & 7.3 & 0.1 & 1.9 & 2 & 0.9 & 0.2 & 1.5 & 5 & 5.0 & 1.0 & 0.1 \\
\hline \multirow[t]{4}{*}{ South } & Low & 1.7 & 4.5 & 0.9 & -1.3 & 0 & 1.3 & 1.0 & -1.8 & 5 & 4.7 & 0.7 & 0.6 \\
\hline & MedLow & 18.7 & 16.6 & 0.4 & 0.4 & 0 & 0.0 & 1.0 & -0.1 & 8 & 7.1 & 0.3 & 1.3 \\
\hline & MedHigh & 8 & 3.4 & 0.01 & 2.6 & 2 & 1.1 & 0.3 & 1.2 & 4 & 4.7 & 1.0 & -1.6 \\
\hline & High & 8 & 12.8 & 0.9 & -1.3 & 0 & 0.3 & 1.0 & -0.6 & 7 & 6.6 & 0.6 & 0.6 \\
\hline \multirow[t]{4}{*}{ West } & Low & 0 & 1.2 & 1.0 & -1.2 & 0 & 0.6 & 1.0 & -1.2 & 3 & 3.0 & 1.0 & 0.0 \\
\hline & MedLow & 5 & 3.9 & 0.4 & 0.6 & 1 & 0.5 & 0.5 & 0.9 & 6 & 5.3 & 0.4 & 1.1 \\
\hline & MedHigh & 2 & 2.0 & 0.8 & 0.0 & 2 & 1.9 & 0.8 & 0.1 & 4 & 3.9 & 1.0 & 0.3 \\
\hline & High & 2.7 & 3.2 & 0.6 & -0.3 & 0 & 0.4 & 1.0 & -0.8 & 5 & 4.9 & 0.8 & 0.1 \\
\hline \multicolumn{14}{|l|}{ ff model } \\
\hline \multirow[t]{4}{*}{ North } & Low & 6.2 & 5.7 & 0.2 & 1.2 & 4 & 4.2 & 1.0 & -0.5 & 6 & 6.2 & 0.9 & -0.4 \\
\hline & MedLow & 4.3 & 4.7 & 1.0 & -1.0 & 1 & 0.8 & 0.8 & 0.3 & 6 & 5.5 & 0.6 & 0.8 \\
\hline & MedHigh & 1.7 & 1.7 & 1.0 & 0.0 & 0 & 0.0 & 1.0 & 0.0 & 5 & 5.0 & 1.0 & 0.0 \\
\hline & High & 4.5 & 4.4 & 0.6 & 0.2 & 5 & 5.0 & 1.0 & 0.0 & 5 & 5.4 & 1.0 & -0.8 \\
\hline \multirow[t]{4}{*}{ East } & Low & 7 & 6.5 & 0.1 & 1.5 & 2 & 1.7 & 0.5 & 0.4 & 7 & 8.2 & 1.0 & -1.6 \\
\hline & MedLow & 17.7 & 18.7 & 1.0 & -1.5 & 2 & 1.1 & 0.3 & 1.2 & 10 & 9.4 & 0.5 & 0.8 \\
\hline & MedHigh & 2 & 2.0 & 1.0 & 0.0 & 0 & 0.0 & 1.0 & 0.0 & 5 & 5.0 & 1.0 & 0.0 \\
\hline & High & 13.3 & 13.8 & 1.0 & -0.9 & 2 & 1.5 & 0.5 & 1.1 & 5 & 5.0 & 1.0 & 0.0 \\
\hline \multirow[t]{4}{*}{ South } & Low & 1.7 & 1.7 & 1.0 & 0.0 & 0 & 0.0 & 1.0 & 0.0 & 5 & 5.0 & 1.0 & 0.0 \\
\hline & MedLow & 18.7 & 18.9 & 0.8 & -0.4 & 0 & 0.0 & 1.0 & 0.0 & 8 & 7.1 & 0.2 & 1.5 \\
\hline & MedHigh & 8 & 6.7 & 0.1 & 2.4 & 2 & 2.0 & 1.0 & 0.0 & 4 & 4.6 & 1.0 & -1.3 \\
\hline & High & 8 & 8.4 & 1.0 & -0.7 & 0 & 0.0 & 1.0 & 0.0 & 7 & 7.0 & 0.8 & -0.1 \\
\hline \multirow[t]{4}{*}{ West } & Low & $\sim$ & & & & $\sim$ & & & & $\sim$ & & & \\
\hline & MedLow & 5 & 5.5 & 1.0 & -0.9 & 1 & 0.9 & 0.8 & 0.3 & 6 & 5.5 & 0.6 & 0.8 \\
\hline & MedHigh & 2 & 2.2 & 1.0 & -0.4 & 2 & 2.0 & 1.0 & 0.0 & 4 & 3.9 & 0.9 & 0.4 \\
\hline & High & 2.7 & 2.7 & 0.5 & 0.0 & 0 & 0.0 & 1.0 & 0.0 & 5 & 5.5 & 1.0 & -1.1 \\
\hline
\end{tabular}

Note: Local scale co-occurrence patterns based on shared microhabitat characteristics of four coexisting ant species on V. erioloba at Kuzikus Wildlife Reserve, Namibia. The presenceabsence matrices analysed represented different microhabitat characteristics, with columns as sites (branches) and rows as species. Two null models were used for the analyses, fixedequiprobable (fe) maintains row sums but allows column totals to vary and fixed-fixed (ff) maintains all row and column totals. C-score is the C-score calculated from the observed assemblages, CHECKER is the number of species forming a checkerboard distribution in the observed assemblages and COMBO is the number of species combinations in the observed assemblages. In the table the first two columns indicate the cardinal direction the branch was facing and the height of branch sampled for all sites in the matrix. $\mathrm{I}_{\mathrm{obs}}$ is the observed value for the index and $\mathrm{I}_{\text {sim }}$ is the mean value of the index based on 5,000 null randomisation matrices. The SES is calculated from $\left(\mathrm{I}_{\mathrm{obs}}-\mathrm{I}_{\mathrm{sim}}\right) / \mathrm{S}_{\text {sim }}$ where $\mathrm{S}_{\text {sim }}$ is the standard deviation of the index based on 5,000 null randomisation matrices. An SES value greater than 2 indicates 
segregation of species and an SES of less than -2 indicates significant species aggregation. Significant $P$ and SES values are highlighted yellow in bold type.

Table A3 Summary of the null model tests for deviations of ant species co-occurrence matrices from randomness using three co-occurrence indices under two null models

\begin{tabular}{llllll}
\hline & Null & Average & & & \\
Index & Model & SES & $n$ & $V$ & $P$ \\
\hline Tree matrices & & & & & \\
C-Score & fe & 0.33 & 17 & 73.5 & 0.91 \\
C-Score & ff & 0.05 & 16 & 17 & 0.94 \\
CHECKER & fe & -0.12 & 18 & 55 & 0.52 \\
CHECKER & ff & -0.02 & 16 & 10 & 1.00 \\
COMBO & fe & 0.10 & 18 & 92 & 0.48 \\
COMBO & ff & 0.07 & 16 & 18 & 0.55 \\
Microhabitat & & & & & \\
matrices & & & & & \\
C-Score & fe & 0.15 & 16 & 71 & 0.90 \\
C-Score & ff & -0.04 & 15 & 34 & 0.72 \\
CHECKER & fe & -0.01 & 16 & 70 & 0.94 \\
CHECKER & ff & 0.19 & 15 & 17 & 0.21 \\
COMBO & fe & 0.27 & 16 & 85 & 0.16 \\
COMBO & ff & -0.06 & 15 & 30 & 0.82 \\
\hline
\end{tabular}

Note: The indices were; CHECKER - the number of species pairs forming a checkerboard distribution, COMBO - the number of species combinations, and C-score - a measure of species co-occurrence. The null models were; Fixed-fixed (ff) $=$ null model in which the matrix row and column sums are preserved; Fixed-equiprobable $(\mathrm{fe})=$ null model in which the rows are fixed and the column total of the matrix are allowed to vary freely. To enable us to make comparisons across matrices, we calculated the standardised effect size (SES) for each matrix as $\left(\mathrm{I}_{\mathrm{obs}}-\mathrm{I}_{\mathrm{sim}}\right) / \mathrm{S}_{\text {sim }}$ where $\mathrm{S}_{\text {sim }}$ is the standard deviation of the index based on 5,000 null randomisation matrices (Gotelli and McCabe 2002). A one-sample Wilcoxon test was used to test the null hypothesis that the mean SES measured for the 20 within-tree presenceabsence matrices and 16 microhabitat presence-absence matrices did not differ from zero. We performed six tests for each set of matrices (three indices $\mathrm{x}$ two null models) and applied a Bonferroni correction for multiple tests $(P<0.05 / 6)$.

Table A4 Results from ANOVA examining the influence of microhabitat variables on cooccurrence indices

\begin{tabular}{lllllll}
\hline & \multicolumn{2}{c}{ CHECKER } & \multicolumn{2}{c}{ C-score } & \multicolumn{2}{c}{ COMBO } \\
\cline { 2 - 6 } & ff & fe & ff & fe & ff & fe \\
\hline SES & & & & & \\
Height of branch & $3.05(0.19)$ & $0.27(0.85)$ & $3.59(0.05)$ & $0.24(0.87)$ & $3.76(0.07)$ & $1.15(0.37)$ \\
Aspect of branch & $1.71(0.32)$ & $0.56(0.65)$ & $0.18(0.91)$ & $0.15(0.93)$ & $0.03(0.99)$ & $0.12(0.95)$ \\
\hline Note: F ratio values of the variables are indicated with $P$ values in brackets. CHECKER = \\
number of species pairs forming a checkerboard distribution; COMBO = number of species \\
combinations. Fixed-fixed (ff) = null model in which the matrix row and column sums are \\
preserved; Fixed-equiprobable (fe) = null model in which the rows are fixed and the column \\
total of the matrix are allowed to vary freely. SES is the standardised effect size.
\end{tabular}


Table A5 Spearman's rank correlation of association of nest sites on branches of V. erioloba for occupant ant species

\begin{tabular}{lllll}
\hline & Cataulacus & Crematogaster & Tapinoma & Tetraponera \\
\hline Cataulacus & - & -0.01 & 0.17 & -0.09 \\
Crematogaster & 0.934 & - & -0.10 & -0.08 \\
Tapinoma & $\mathbf{0 . 0 1 4}$ & 0.161 & - & -0.05 \\
Tetraponera & 0.211 & 0.275 & 0.476 & - \\
\hline
\end{tabular}

Note: Above the diagonal indicates the estimated measure of association, Spearman's rho statistic, below the diagonal indicates $P$ values with significant values in bold. 
Table A6 Summary of ant-myrmecophyte systems with particular reference to species occupancy state, and rate of plant and domatia occupancy

\begin{tabular}{|c|c|c|c|c|}
\hline Plant species & Ant species & $\begin{array}{l}\text { Number } \\
\text { of ant } \\
\text { species }\end{array}$ & $\begin{array}{l}\text { Occupancy rate } \\
\text { of plants }(\%)\end{array}$ & $\begin{array}{l}\text { Occupancy } \\
\text { rate of } \\
\text { domatia }\end{array}$ \\
\hline
\end{tabular}

(\%)

\section{SINGLE-SPECIES \\ OCCUPANCY (SSO)}

\section{STATE}

Barteria fistulosa

Cecropia concolor

Cecropia distachya

Cecropia purpurascens

Cecropia ulei

Cordia nodosa

Duroia hirsute

Hirtella myrmecophila

Korthalsia furtadoana

Leonardoxa africana

Macaranga bancana

Macaranga beccariana

Macaranga havilandii

Macaranga hosei

Macaranga hosei

Macaranga hulletti

Macaranga hullettii

Macaranga hypoleuca

Macaranga kingii

Macaranga lamellata

Macaranga trachyphylla

Macaranga triloba

Macaranga winkleri

Maieta guianensis

Piper cenocladum

Ryparosa fasciculata

Tachigali myrmecophila

Tococa bullifera

Tococa guianensis

Tococa guianensis

Tococa spadaciflora
Pachysima spp.

Azteca alfari

Az. alfari

Az. alfari

Az. alfari

Az. depilis + 4 spp.

Az. depilis; Myrmelachista schumanni

Allomerus octoarticulatus

Camponotus spp. + others

Petalomyrmex phylax; Cataulacus mckeyi

Crematogaster borneensis

$\mathrm{Cr}$ decamera

Cr. decamera

Crematogaster sp.

Cr. borneensis

Cr. borneensis

Cr. borneensis

Cr. borneensis

Cr. borneensis

Cr. decamera; Camponotus macarangae

Cr. borneensis

Cr. borneensis

Crematogaster spp.

Mixed assemblage

Pheidole bicornis

Cladomyrma spp. + others

Ps. concolor + others

Cr. laevis; Azteca sp. + others

Az. bequaerti; Cr. laevis $+10 \mathrm{spp}$.

Pheidole sp.; Crematogaster sp.+ others

Pheidole sp.; Crematogaster $\mathrm{sp} .+2 \mathrm{spp}$. $60(n=68)$

52.8

85.5

80

46.8

80

$97(\mathrm{n}=600)$

92

100

100

100

100

$41(n=139)$

100

$66(n=109)$

$64(n=159)$

100

100

100

$68(\mathrm{n}=348)$

100

$70(n=23)$

100

91.5-100

67

Approx. 96

98
(Janzen 1972)

Vasconcelos and Casimiro 1997)

Vasconcelos and Casimiro 1997)

(Vasconcelos and Casimiro 1997)

(Vasconcelos and Casimiro 1997)

(Frederickson 2005)

(Frederickson 2005)

(Izzo and Vasconcelos 2002)

(Edwards et al. 2010)

(Gaume and McKey 1999; Gaume et al. 1997)

(Itino and Itioka 2001; Itino et al. 2001)

(Itino and Itioka 2001; Itino et al. 2001)

(Itino and Itioka 2001; Itino et al. 2001)

(Itino and Itioka 2001; Itino et al. 2001)

(Fiala et al. 1989)

(Itino and Itioka 2001; Itino et al. 2001)

(Fiala et al. 1989)

(Fiala et al. 1989)

(Itino and Itioka 2001; Itino et al. 2001)

(Itino and Itioka 2001; Itino et al. 2001)

(Itino and Itioka 2001; Itino et al. 2001)

(Fiala et al. 1989)

(Itino and Itioka 2001; Itino et al. 2001)

(Joly et al. 2014; Valentini et al. 2009)

(Dyer and Letourneau 1999)

(Webber et al. 2007)

(Fonseca 1994)

(Joly et al. 2014)

(Valentini et al. 2009)

(Alvarez et al. 2001)

(Alvarez et al. 2001) 


Vachellia allenii
Vachellia chiapensis
Vachellia collinsii
Vachellia melanoceras
Vachellia drepanolobium
Vachellia hindsii
Vachellia seyal var. fistula
UNKNOWN OCCUPANCY
STATE
Caularthron bilamellatum

Ficus obscura var borneensis

Piper sagittifolium

Tillandsia bulbosa

Tococa coronate

Tococa macrosperma

Vachellia cornigera

Vachellia ruddiae

Vachellia sphaerocephala

Vachellia zanzibarica

MULTIPLE SPECIES CO-

OCCUPANCY (MSC)

\section{STATE}

Humboldtia brunonis*1

Myrmecophila christinae ${ }^{* 2}$

Myrmecophila christinae ${ }^{* 2}$

Myrmecophila christinae*2

Vachellia mayana*3

Zanthoxylum myriacanthum $* 4$

Ps. ferruginea

Ps. ferruginea; unidentified $\mathrm{sp}$

Pseudomyrmex spp.

Ps. satanica

Mixed assemblage

Ps. ferruginea; Ps. veneficus

Crematogaster spp.; Lepisota canescens

Mixed assemblage

Mixed assemblage

Pheidole bicornis

Mixed assemblage

Az. spp.; Ps. spp.

Crematogaster spp.; Allomerus spp.

Camponotus planatus

Mixed assemblage

Crematogaster spp. + others

Crematogaster spp.

Mixed assemblage

Mixed assemblage

Mixed assemblage

Mixed assemblage

Ps. ferrugineus; Camponotus planatus

Mixed assemblage

$\begin{array}{ll}\sim & \sim \\ \sim & \sim \\ \sim & \sim \\ \sim & \sim \\ \sim & \sim\end{array}$

$\tilde{\sim}$

$85(\mathrm{n}=573)$

$58(\mathrm{n}=100)$

Many

Many

Many

Many

\author{
(Janzen 1974) \\ (Janzen 1974) \\ (Janzen 1974) \\ (Janzen 1974) \\ (Stapley 1998; Young et al. 1997) \\ (Janzen 1974; Raine et al. 2002) \\ (Young et al. 1997)
}

(Fisher 1992; Fisher and Zimmerman 1988 )

Maschwitz et al. 1994)

(Letourneau 1998)

(Dejean et al. 1995)

(Michelangeli 2003)

(Michelangeli 2003)

(Janzen 1974)

Janzen 1974)

(Janzen 1974)

(Cochard et al. 2008)

(Gaume et al. 2005a; Gaume et al. 2005b)

(Dejean et al. 1995)

(Rico-Gray and Thien 1989a; Rico-Gray and

Thien 1989b)

(Dejean et al. 2003)

(Raine et al. 2004)

(Moog et al. 2002)

Note: Studies were selected if they featured in either of three meta-analyses (Chamberlain and Holland 2009; Rosumek et al. 2009; Trager et al. 2010) that incorporated 76, 59 and 81 primary studies of ant-plant mutualisms. A large majority of these primary studies were on myrmecophilic plants (plants provide food resources but no housing) and we therefore excluded them from this summary, reducing the number of primary studies listed here to 34 . The studies represent 49 myrmecophyte species, although some species are included in the table multiple times to allow presentation of separate datasets. Occupancy of plants and domatia are given as percentages; the number in parentheses is the total sample size of either plants or domatia; indicates that the data were not reported in the study. On Vachellia ruddiae $20 \%$ of insect occupied thorns were inhabited by one of seven ant species, however no figure for overall domatia occupancy rate by ants was available. 
Although seven ant species are found in domatia on the semi-myrmecophyte Humboldtia brunonis ${ }^{* 1}$ there is one particular species that exclusively occupies host plants, whereas the remaining six species can co-occur simultaneously on the same tree (Gaume et al. 2005a; Gaume et al. 2005b). In the orchid, Myrmecophila christinae ${ }^{* 2}$ (formerly Schomburgkia tibicinis), hollow pseudobulbs house ants and several species occur on an individual plant, although never within the same pseudobulb. Despite coexisting on M. christinae ants remain strongly territorial and only a single species controls foraging access to extrafloral nectar on a plant spike (Rico-Gray and Thien 1989a; Rico-Gray and Thien 1989b).

The Mexican swollen-thorn acacia, Vachellia mayana*3 is co-occupied by two ant species, Pseudomyrmex ferrugineus and Camponotus planatus on $30.7 \%$ of mature plants. The mutualist ant $P$. ferrugineus occupied swollen-thorns near branch tips whereas the parasitic ant $C$. planatus generally occupied old or damaged domatia (Raine et al. 2004). The SE Asian myrmecophyte Zanthoxylum myriacanthum ${ }^{* 4}$ possesses hollowstem domatia that have slit like openings for ant access, which close over if not used as nest sites (Moog et al. 2002). Data on the number of myrmecophytes with multiple species co-occupancy (MSC) by different ants were only available for $V$. mayana (31\% of plants show MSC) and Z. myriacanthum ( $83 \%$ of plants show MSC). 
Literature cited only in appendix A

Albrecht, M., and N. J. Gotelli. 2001. Spatial and temporal niche partitioning in grassland ants. Oecologia 126:134-141.

Alvarez, G., I. Armbrecht, E. Jiménezl, H. Armbrecht, and P. Ulloa-Chaconl. 2001. Ant-plant association in two Tococa species from a primary rain forest of Colombian Choco (Hymenoptera: Formicidae). Sociobiology 38:585-602.

Belinchón, R., I. Martínez, G. Aragón, and A. Escudero. 2012. Lichen species co-occurrence patterns along an edge-interior Mediterranean forest gradient. Acta Oecologica 43:150-157.

Chamberlain, S. A., and J. N. Holland. 2009. Quantitative synthesis of context dependency in ant-plant protection mutualisms. Ecology 90:2384-2392.

Cochard, R., D. Agosti, T. M. Palmer, M. L. Stanton, T. P. Young, J. R. Goheen, R. M. Pringle et al. 2008. Putting ant-Acacia mutualisms to the fire. Science 319:1759d1761.

Dejean, A., S. Durou, I. Olmsted, R. R. Snelling, and J. Orivel. 2003. Nest site selection by ants in a flooded Mexican mangrove, with special reference to the epiphytic orchid Myrmecophila christinae. Journal of Tropical Ecology 19:325-331.

Dejean, A., I. Olmsted, and R. R. Snelling. 1995. Tree-epiphyte-ant relationships in the low inundated forest of Sian Ka'an Biosphere Reserve, Quintana Roo, Mexico. Biotropica 27:57-70.

Diamond, J. M. 1975. Assembly of species communities, Pages 342-444 in M. L. Cody, and J. M. Diamond, eds. Ecology and evolution of communities. Cambridge, Massachusetts, USA, Harvard University Press.

Dyer, L. A., and D. K. Letourneau. 1999. Relative strengths of top-down and bottom-up forces in a tropical forest community. Oecologia 119:265-274.

Edwards, D. P., F. A. Ansell, P. Woodcock, T. M. Fayle, V. K. Chey, and K. C. Hamer. 2010. Can the failure to punish promote cheating in mutualism? Oikos 119:45-52.

Fiala, B., U. Maschwitz, T. Y. Pong, and A. J. Helbig. 1989. Studies of a South East Asian ant-plant association: protection of Macaranga trees by Crematogaster borneensis. Oecologia 79:463-470.

Fisher, B. L. 1992. Facultative ant association benefits a Neotropical orchid. Journal of Tropical Ecology 8:109-114.

Fisher, B. L., and J. K. Zimmerman. 1988. Ant/orchid associations in the Barro Colorado National Monument, Panama. Lindleyana 3:12-16.

Fonseca, C. R. 1994. Herbivory and the long-lived leaves of an Amazonian ant-tree. Journal of Ecology 82:833-842.

Fonseca, C. R., and G. Ganade. 1996. Asymmetries, compartments and null interactions in an Amazonian ant-plant community. Journal of Animal Ecology 65:339-347.

Frederickson, M. E. 2005. Ant species confer different partner benefits on two Neotropical myrmecophytes. Oecologia 143:387-395.

Gaume, L., and D. McKey. 1999. An ant-plant mutualism and its host-specific parasite: activity rhythms, young leaf patrolling, and effects on herbivores of two specialist plant-ants inhabiting the same myrmecophyte. Oikos 84:130-144. 
Gaume, L., D. McKey, and M.-C. Anstett. 1997. Benefits conferred by "timid" ants: active anti-herbivore protection of the rainforest tree Leonardoxa africana by the minute ant Petalomyrmex phylax. Oecologia 112:209-216.

Gaume, L., M. Zacharias, and R. Borges. 2005a. Ant-plant conflicts and a novel case of castration parasitism in a myrmecophyte. Evolutionary Ecology Research 7:435-452.

Gaume, L., M. Zacharias, V. Grosbois, and R. M. Borges. 2005b. The fitness consequences of bearing domatia and having the right ant partner: experiments with protective and non-protective ants in a semi-myrmecophyte. Oecologia 145:76-86.

Gotelli, N. J. 2000. Null model analysis of species co-occurrence patterns. Ecology 81:26062621.

Gotelli, N. J., and A. M. Ellison. 2002. Assembly rules for New England ant assemblages. Oikos 99:591-599.

Gotelli, N. J., and G. L. Entsminger. 2009.EcoSim: Null models software for ecology. Version 7.Acquired Intelligence Inc. \& Kesey-Bear, Jericho, VT 05465.

Gotelli, N. J., and D. J. McCabe. 2002. Species co-occurrence: a meta-analysis of JM Diamond's assembly rules model. Ecology 83:2091-2096.

Gotelli, N. J., and W. Ulrich. 2012. Statistical challenges in null model analysis. Oikos 121:171-180.

Gove, A. D., J. D. Majer, and V. Rico-Gray. 2009. Ant assemblages in isolated trees are more sensitive to species loss and replacement than their woodland counterparts. Basic and Applied Ecology 10:187-195.

Itino, T., and T. Itioka. 2001. Interspecific variation and ontogenetic change in antiherbivore defense in myrmecophytic Macaranga species. Ecological Research 16:765-774.

Itino, T., T. Itioka, A. Hatada, and A. A. Hamid. 2001. Effects of food rewards offered by ant-plant Macaranga on the colony size of ants. Ecological Research 16:775-786.

Izzo, T., and H. Vasconcelos. 2002. Cheating the cheater: domatia loss minimizes the effects of ant castration in an Amazonian ant-plant. Oecologia 133:200-205.

Janzen, D. H. 1972. Protection of Barteria (Passifloraceae) by Pachysima ants (Pseudomyrmecinae) in a Nigerian rain forest. Ecology 53:885-892.

- 1974. Swollen-thorn acacias of Central America. Smithsonian Contributions to Botany. 13:1-131.

Joly, S., T. J. Davies, A. Archambault, A. Bruneau, A. Derry, S. W. Kembel, P. Peres-Neto et al. 2014. Ecology in the age of DNA barcoding: The resource, the promise and the challenges ahead. Molecular Ecology Resources 14:221-232.

Letourneau, D. K. 1998. Ants, stem-borers, and fungal pathogens: Experimental tests of a fitness advantage in Piper ant-plants. Ecology 79:593-603.

Maschwitz, U., B. Fiala, L. G. Saw, Y. Norma-Rashid, and A. H. Idris. 1994. Ficus obscura var. borneensis (Moraceae), a new non-specific ant-plant from Malesia. Malayan Nature Journal 47:409 - 416.

Michelangeli, F. A. 2003. Ant protection against herbivory in three species of Tococa (Melastomataceae) occupying different environments. Biotropica 35:181-188.

Moog, J., H. Feldhaar, and U. Maschwitz. 2002. On the caulinary domatia of the SE-Asian ant-plant Zanthoxylum myriacanthum Wall. ex Hook. f.(Rutaceae) and the protection against herbivory. Sociobiology 40. 
R Core Development Team. 2012.R: A language and environment for statistical computing. R Foundation for Statistical Computing, Vienna, Austria.

Raine, N. E., N. Gammans, I. J. Macfadyen, G. K. Scrivner, and G. N. Stone. 2004. Guards and thieves: antagonistic interactions between two ant species coexisting on the same ant-plant. Ecological Entomology 29:345-352.

Raine, N. E., P. Willmer, and G. N. Stone. 2002. Spatial structuring and floral avoidance behavior prevent ant-pollinator conflict in a Mexican ant-Acacia. Ecology 83:30863096.

Rico-Gray, V., and L. B. Thien. 1989a. Ant-mealybug interaction decreases reproductive fitness of Schomburgkia tibicinis (Orchidaceae) in Mexico. Journal of Tropical Ecology 5:109-112.

Rico-Gray, V., and L. B. Thien. 1989b. Effect of different ant species on reproductive fitness of Schomburgkia tibicinis (Orchidaceae). Oecologia 81:487-489.

Rosumek, F. B., F. A. O. Silveira, F. d. S. Neves, P. d. U. B. Newton, L. Diniz, Y. Oki, F. Pezzini et al. 2009. Ants on plants: a meta-analysis of the role of ants as plant biotic defenses. Oecologia 160:537-549.

Sanders, N. J., N. J. Gotelli, S. E. Wittman, J. S. Ratchford, A. M. Ellison, and E. S. Jules. 2007. Assembly rules of ground-foraging ant assemblages are contingent on disturbance, habitat and spatial scale. Journal of Biogeography 34:1632-1641.

Stapley, L. 1998. The interaction of thorns and symbiotic ants as an effective defence mechanism of swollen-thorn Acacias. Oecologia 115:401-405.

Stone, L., and A. Roberts. 1990. The checkerboard score and species distributions. Oecologia 85:74-79.

Trager, M. D., S. Bhotika, J. A. Hostetler, G. V. Andrade, M. A. Rodriguez-Cabal, C. S. McKeon, C. W. Osenberg et al. 2010. Benefits for plants in ant-plant protective mutualisms: a meta-analysis. PLoS ONE 5:e14308.

Ulrich, W., and N. J. Gotelli. 2013. Pattern detection in null model analysis. Oikos 122:2-18.

Valentini, A., F. Pompanon, and P. Taberlet. 2009. DNA barcoding for ecologists. Trends in Ecology \& Evolution 24:110-117.

Vasconcelos, H. L., and A. B. Casimiro. 1997. Influence of Azteca alfari ants on the exploitation of Cecropia trees by a leaf-cutting ant. Biotropica 29:84-92.

Webber, B. L., J. Moog, A. S. O. Curtis, and I. A. N. E. Woodrow. 2007. The diversity of ant-plant interactions in the rainforest understorey tree, Ryparosa (Achariaceae): food bodies, domatia, prostomata, and hemipteran trophobionts. Botanical Journal of the Linnean Society 154:353-371.

Young, T. P., C. H. Stubblefield, and L. A. Isbell. 1997. Ants on swollen thorn acacias: species coexistence in a simple system. Oecologia 109:98-107. 
Literature cited

Adam, T. C. 2010. Competition encourages cooperation: client fish receive higher-quality service when cleaner fish compete. Animal Behaviour 79:1183-1189.

Belinchón, R., I. Martínez, G. Aragón, and A. Escudero. 2012. Lichen species co-occurrence patterns along an edge-interior Mediterranean forest gradient. Acta Oecologica 43:150-157.

Byrne, M. M. 1994. Ecology of twig-dwelling ants in a wet lowland tropical forest. Biotropica 26:61-72.

Campbell, H., M. D. E. Fellowes, and J. M. Cook. 2013a. Arboreal thorn-dwelling ants coexisting on the savannah ant-plant, Vachellia erioloba, use domatia morphology to select nest sites. Insectes Sociaux 60:373-382.

Campbell, H., M. D. E. Fellowes, and J. M. Cook. 2015. Data from: The curious case of the camelthorn: competition, coexistence and nest-site limitation in a multispecies mutualism. American Naturalist. Dryad Digital Repository, doi:10.5061/dryad.s9f7c

Campbell, H., I. Townsend, M. D. E. Fellowes, and J. M. Cook. 2013b. Thorn-dwelling ants provide antiherbivore defence for camelthorn trees, Vachellia erioloba, in Namibia. African Journal of Ecology 51:590-598.

Cerdá, X., X. Arnan, and J. Retana. 2013. Is competition a significant hallmark of ant (Hymenoptera: Formicidae) ecology? Myrmecological News 18:131-147.

Chamberlain, S. A., and J. N. Holland. 2009. Quantitative synthesis of context dependency in ant-plant protection mutualisms. Ecology 90:2384-2392.

Clement, L. W., S. C. W. Koppen, W. A. Brand, and M. Heil. 2008. Strategies of a parasite of the ant-acacia mutualism. Behavioral Ecology and Sociobiology 62:953-962.

Crawley, M. J. 2005, Statistics: an introduction using R. Chichester, UK, John Wiley \& Sons Ltd.

Davidson, D. W., and D. McKey. 1993. The evolutionary ecology of symbiotic ant-plant relationships. Journal of Hymenoptera Research 2:13-83.

Davidson, D. W., R. R. Snelling, and J. T. Longino. 1989. Competition among ants for myrmecophytes and the significance of plant trichomes. Biotropica 21:64-73.

de Vega, C., M. Arista, P. L. Ortiz, C. M. Herrera, and S. Talavera. 2009. The ant-pollination system of Cytinus hypocistis (Cytinaceae), a Mediterranean root holoparasite. Annals of Botany 103:1065-1075.

Dejean, A., B. Corbara, J. Orivel, and M. Leponce. 2007. Rainforest canopy ants: the implications of territoriality and predatory behavior. Functional Ecosystems and Communities 1:105-120.

Dejean, A., F. Petitclerc, O. Roux, J. Orivel, and C. Leroy. 2012. Does exogenic food benefit both partners in an ant-plant mutualism? The case of Cecropia obtusa and its guest Azteca plant-ants. Comptes Rendus Biologies 335:214-219.

Dharani, N. 2006, Field guide to Acacias of East Africa. Cape Town, Struik Publishers.

Diamond, J. M. 1975. Assembly of species communities, Pages 342-444 in M. L. Cody, and J. M. Diamond, eds. Ecology and evolution of communities. Cambridge, Massachusetts, USA, Harvard University Press.

Djiéto-Lordon, C., A. Dejean, R. A. Ring, B. A. Nkongmeneck, J. Lauga, and D. McKey. 2005. Ecology of an improbable association: the pseudomyrmecine plant-ant Tetraponera tessmanni and the myrmecophytic liana Vitex thyrsiflora (Lamiaceae) in Cameroon. Biotropica 37:421-430.

Dyer, L. A., and D. K. Letourneau. 1999. Relative strengths of top-down and bottom-up forces in a tropical forest community. Oecologia 119:265-274. 
Edwards, D. P., F. A. Ansell, P. Woodcock, T. M. Fayle, V. K. Chey, and K. C. Hamer. 2010. Can the failure to punish promote cheating in mutualism? Oikos 119:45-52.

Edwards, D. P., M. Hassall, W. J. Sutherland, and D. W. Yu. 2006. Selection for protection in an ant-plant mutualism: host sanctions, host modularity, and the principal-agent game. Proceedings of the Royal Society B-Biological Sciences 273:595-602.

Fayle, T. M., D. P. Edwards, E. C. Turner, A. J. Dumbrell, P. Eggleton, and W. A. Foster. 2011. Public goods, public services and by-product mutualism in an ant-fern symbiosis. Oikos 121:1279-1286.

Fonseca, C. R. 1993. Nesting space limits colony size of the plant-ant Pseudomyrmex concolor. Oikos 67:473-482.

-. 1999. Amazonian ant-plant interactions and the nesting space limitation hypothesis. Journal of Tropical Ecology 15:807-825.

Frederickson, M. E. 2005. Ant species confer different partner benefits on two Neotropical myrmecophytes. Oecologia 143:387-395.

Gallegos, S. C., I. Hensen, and M. Schleuning. 2014. Secondary dispersal by ants promotes forest regeneration after deforestation. Journal of Ecology 102:659-666.

Gaume, L., and D. McKey. 1999. An ant-plant mutualism and its host-specific parasite: activity rhythms, young leaf patrolling, and effects on herbivores of two specialist plant-ants inhabiting the same myrmecophyte. Oikos 84:130-144.

Gaume, L., M. Zacharias, and R. Borges. 2005a. Ant-plant conflicts and a novel case of castration parasitism in a myrmecophyte. Evolutionary Ecology Research 7:435-452.

Gaume, L., M. Zacharias, V. Grosbois, and R. M. Borges. 2005b. The fitness consequences of bearing domatia and having the right ant partner: experiments with protective and non-protective ants in a semi-myrmecophyte. Oecologia 145:76-86.

Gotelli, N. J., and G. L. Entsminger. 2009.EcoSim: Null models software for ecology. Version 7.Acquired Intelligence Inc. \& Kesey-Bear, Jericho, VT 05465.

Gotelli, N. J., and D. J. McCabe. 2002. Species co-occurrence: a meta-analysis of JM Diamond's assembly rules model. Ecology 83:2091-2096.

Harpole, W. S., and D. Tilman. 2007. Grassland species loss resulting from reduced niche dimension. Nature 446:791-793.

Heil, M., and D. McKey. 2003. Protective ant-plant interactions as model systems in ecological and evolutionary research. Annual Review of Ecology, Evolution, and Systematics 34:425-453.

Itioka, T., M. Nomura, Y. Inui, T. Itino, and T. Inoue. 2000. Difference in intensity of ant defense among three species of Macaranga myrmecophytes in a southeast Asian dipterocarp forest. Biotropica 32:318-326.

Jackson, D. A. 1984. Ant distribution patterns in a Cameroonian cocoa plantation: investigation of the ant mosaic hypothesis. Oecologia 62:318-324.

Janzen, D. H. 1974. Swollen-thorn acacias of Central America. Smithsonian Contributions to Botany. 13:1-131.

Kautz, S., D. J. Ballhorn, J. Kroiss, S. U. Pauls, C. S. Moreau, S. Eilmus, E. Strohm et al. 2012. Host plant use by competing acacia-ants: mutualists monopolize while parasites share hosts. PLoS ONE 7:e37691.

Lange, D., and K. Del-Claro. 2014. Ant-plant interaction in a tropical savanna: may the network structure vary over time and influence on the outcomes of associations? PLoS ONE 9:e105574.

Longino, J. T. 1989. Geographic variation and community structure in an ant-plant mutualism: Azteca and Cecropia in Costa Rica. Biotropica 21:126-132. 
Maschwitz, U., B. Fiala, L. G. Saw, Y. Norma-Rashid, and A. H. Idris. 1994. Ficus obscura var. borneensis (Moraceae), a new non-specific ant-plant from Malesia. Malayan Nature Journal 47:409 - 416.

Mayer, V. E., M. E. Frederickson, D. McKey, and R. Blatrix. 2014. Current issues in the evolutionary ecology of ant-plant symbioses. New Phytologist 202:749-764.

Michelangeli, F. A. 2003. Ant protection against herbivory in three species of Tococa (Melastomataceae) occupying different environments. Biotropica 35:181-188.

Moog, J., H. Feldhaar, and U. Maschwitz. 2002. On the caulinary domatia of the SE-Asian ant-plant Zanthoxylum myriacanthum Wall. ex Hook. f.(Rutaceae) and the protection against herbivory. Sociobiology 40.

Moraes, S. C., and H. L. Vasconcelos. 2009. Long-term persistence of a Neotropical ant-plant population in the absence of obligate plant-ants. Ecology 90:2375-2383.

Nomura, M., A. Hatada, and T. Itioka. 2011. Correlation between the leaf turnover rate and anti-herbivore defence strategy (balance between ant and non-ant defences) amongst ten species of Macaranga (Euphorbiaceae). Plant Ecology 212:143-155.

Palmer, T. M. 2003. Spatial habitat heterogeneity influences competition and coexistence in an African Acacia ant guild. Ecology 84:2843-2855.

- 2004. Wars of attrition: colony size determines competitive outcomes in a guild of African acacia ants. Animal Behaviour 68:993-1004.

Palmer, T. M., D. F. Doak, M. L. Stanton, J. L. Bronstein, E. T. Kiers, T. P. Young, J. R. Goheen et al. 2010. Synergy of multiple partners, including freeloaders, increases host fitness in a multispecies mutualism. Proceedings of the National Academy of Sciences 107:17234-17239.

Palmer, T. M., M. L. Stanton, and T. P. Young. 2003. Competition and coexistence: exploring mechanisms that restrict and maintain diversity within mutualist guilds. The American Naturalist 162:S63-S79.

Palmer, T. M., M. L. Stanton, T. P. Young, J. R. Goheen, R. M. Pringle, and R. Karban. 2008. Breakdown of an ant-plant mutualism follows the loss of large herbivores from an African savanna. Science 319:192-195.

Palmer, T. M., T. P. Young, M. L. Stanton, and E. Wenk. 2000. Short-term dynamics of an Acacia ant community in Laikipia, Kenya. Oecologia 123:425-435.

Parr, C. L., and H. Gibb. 2010. Competition and the role of dominant ants, Pages 77-96 in L. Lach, C. L. Parr, and K. L. Abbott, eds. Ant Ecology. Oxford, UK, Oxford University Press.

Parr, C. L., B. Sinclair, J., A. N. Andersen, K. J. Gaston, and S. L. Chown. 2005. Constraint and competition in assemblages: a cross-continental and modeling approach for ants. The American Naturalist 165:481-494.

Philpott, S. M., and P. F. Foster. 2005. Nest-site limitation in coffee agroecosystems: artificial nests maintain diversity of arboreal ants. Ecological Applications 15:14781485.

Raine, N. E., N. Gammans, I. J. Macfadyen, G. K. Scrivner, and G. N. Stone. 2004. Guards and thieves: antagonistic interactions between two ant species coexisting on the same ant-plant. Ecological Entomology 29:345-352.

Rico-Gray, V., and L. B. Thien. 1989a. Ant-mealybug interaction decreases reproductive fitness of Schomburgkia tibicinis (Orchidaceae) in Mexico. Journal of Tropical Ecology 5:109-112.

Rico-Gray, V., and L. B. Thien. 1989b. Effect of different ant species on reproductive fitness of Schomburgkia tibicinis (Orchidaceae). Oecologia 81:487-489.

Room, P. M. 1971. The relative distributions of ant species in Ghana's cocoa farms. The Journal of Animal Ecology 40:735-751. 
—. 1975. Relative distributions of ant species in cocoa plantations in Papua New Guinea. The Journal of Applied Ecology 12:47-61.

Rosumek, F. B., F. A. O. Silveira, F. d. S. Neves, P. d. U. B. Newton, L. Diniz, Y. Oki, F. Pezzini et al. 2009. Ants on plants: a meta-analysis of the role of ants as plant biotic defenses. Oecologia 160:537-549.

Stanton, M. L., and T. M. Palmer. 2011. The high cost of mutualism: effects of four species of East African ant symbionts on their myrmecophyte host tree. Ecology 92:10731082.

Stanton, M. L., T. M. Palmer, and T. P. Young. 2002. Competition-colonization trade-offs in a guild of African Acacia-ants. Ecological Monographs 72:347-363.

- 2005. Ecological barriers to early colony establishment in three coexisting Acacia-ant species in Kenya. Insectes Sociaux 52:393-401.

R Core Development Team. 2012. R: A language and environment for statistical computing.R Foundation for Statistical Computing, Vienna, Austria.

Thompson, J. N. 2005, The geographic mosaic of coevolution. Chicago, University of Chicago Press.

Trager, M. D., S. Bhotika, J. A. Hostetler, G. V. Andrade, M. A. Rodriguez-Cabal, C. S. McKeon, C. W. Osenberg et al. 2010. Benefits for plants in ant-plant protective mutualisms: a meta-analysis. PLoS ONE 5:e14308.

Wagner, D., and E. Fleur Nicklen. 2010. Ant nest location, soil nutrients and nutrient uptake by ant-associated plants: does extrafloral nectar attract ant nests and thereby enhance plant nutrition? Journal of Ecology 98:614-624.

Webber, B. L., J. Moog, A. S. O. Curtis, and I. A. N. E. Woodrow. 2007. The diversity of ant-plant interactions in the rainforest understorey tree, Ryparosa (Achariaceae): food bodies, domatia, prostomata, and hemipteran trophobionts. Botanical Journal of the Linnean Society 154:353-371.

Weber, M. G., and K. H. Keeler. 2013. The phylogenetic distribution of extrafloral nectaries in plants. Annals of Botany 111:1251-1261.

Young, T. P., C. H. Stubblefield, and L. A. Isbell. 1997. Ants on swollen thorn acacias: species coexistence in a simple system. Oecologia 109:98-107.

Yu, D. W., H. B. Wilson, M. E. Frederickson, W. Palomino, R. D. L. Colina, D. P. Edwards, and A. A. Balareso. 2004. Experimental demonstration of species coexistence enabled by dispersal limitation. Journal of Animal Ecology 73:1102-1114. 
Table 1 Summary of myrmecophytic plants that exhibit multiple species co-occupancy (MSC) by their resident ant species.

\begin{tabular}{|c|c|c|c|c|c|c|c|}
\hline & $\begin{array}{l}\text { Plant and domatia } \\
\text { type }\end{array}$ & Habitat & Country & Common domatia-inhabiting ant species & $\begin{array}{l}\text { Number } \\
\text { of ant } \\
\text { species }\end{array}$ & $\begin{array}{l}\text { Plant/ } \\
\text { domatia } \\
\text { occupancy } \\
(\%)\end{array}$ & $\begin{array}{l}\text { MSC } \\
\text { occupancy } \\
(\%)\end{array}$ \\
\hline $\begin{array}{l}\text { Humboldtia brunonis } \\
\text { (Fabaceae, Caesalpinioideae) }\end{array}$ & $\begin{array}{l}\text { Tree with hollow } \\
\text { internodes }\end{array}$ & $\begin{array}{l}\text { Wet } \\
\text { evergreen } \\
\text { forest }\end{array}$ & India & Unknown & 7 & $100 /-$ & - \\
\hline \multirow[t]{3}{*}{$\begin{array}{l}\text { Myrmecophila christinae } \\
\text { (Orchidaceae, Epidendroideae) }\end{array}$} & $\begin{array}{l}\text { Epiphyte with } \\
\text { hollow } \\
\text { pseudobulbs }\end{array}$ & $\begin{array}{l}\text { Coastal } \\
\text { sand dune } \\
\text { mattoral }\end{array}$ & Mexico & $\begin{array}{l}\text { Crematogaster brevispinosa, } \\
\text { Camponotus planatus, Ca. abdominalis, } \\
\text { Ca. rectangularis and Ectatomma } \\
\text { tuberculatum }\end{array}$ & 13 & $-/-$ & - \\
\hline & & $\begin{array}{l}\text { Flooded } \\
\text { mangrove } \\
\text { forest }\end{array}$ & & $\begin{array}{l}\text { Dolichoderus bispinosus and } \\
\text { Pachycondyla villosa }\end{array}$ & 18 & $77.2 /-$ & - \\
\hline & & & & $\begin{array}{l}\text { Ca. planatus, Cyphomyrmex minutus and } \\
\text { Monomorium ebeninum }\end{array}$ & 20 & 85/- & - \\
\hline $\begin{array}{l}\text { Vachellia erioloba } \\
\text { (Fabaceae, Mimosoideae) }\end{array}$ & $\begin{array}{l}\text { Tree with } \\
\text { swollen-thorns }\end{array}$ & Savanna & Namibia & $\begin{array}{l}\text { Crematogaster sp., Cataulacus intrudens, } \\
\text { Tapinoma sp. and Tetraponera ambigua }\end{array}$ & 4 & $100 / 37.45$ & 95 \\
\hline $\begin{array}{l}\text { Vachellia mayana } \\
\text { (Fabaceae, Mimosoideae) }\end{array}$ & $\begin{array}{l}\text { Shrub/small tree } \\
\text { with swollen- } \\
\text { thorns }\end{array}$ & $\begin{array}{l}\text { Lowland } \\
\text { wet forest }\end{array}$ & Mexico & Pseudomyrmex ferrugineus; Ca. planatus & 2 & 100/- & 30.7 \\
\hline $\begin{array}{l}\text { Zanthoxylum myriacanthum } \\
\text { (Rutaceae,_Toddalioideae) }\end{array}$ & $\begin{array}{l}\text { Tree with hollow- } \\
\text { stems }\end{array}$ & $\begin{array}{l}\text { Lowland } \\
\text { forest }\end{array}$ & Malaysia & $\begin{array}{l}\text { Many species including, Cataulacus, } \\
\text { Crematogaster, Tapinoma, } \\
\text { Technomyrmex, Camponotus and } \\
\text { Tetraponera }\end{array}$ & 28 & $62 * / 42$ & 83 \\
\hline
\end{tabular}

are given as percentages and - indicates that the data were not reported in the study. MSC occupancy is the percentage of plants that are occupied by colonies of multiple different ant species nesting within domatia. *On Zanthoxylum myriacanthum $62 \%$ of all trees sampled (including those with only closed stem domatia) were occupied by ants, however $100 \%$ of all trees sampled with open hollow-stem domatia were occupied by ants. 
Figure legends

Figure 1 A, Vachellia erioloba, camelthorn tree in acacia-dominated savanna at Kuzikus Wildlife Reserve, Namibia. B, Swollen-thorn domatia of $V$. erioloba with ant nest entrance hole visible on left thorn. C, Open swollen-thorn domatia containing a Tapinoma nest.

Figure 2 Occupation of nest-sites and numerical dominance of four ant species on V. erioloba at Kuzikus Wildlife Reserve. White bars represent each species as a proportion of the total number of ant nests found on trees. Black bars represent each species as a proportion of the total number of individuals (including workers, alates, queens, and brood) recorded during surveying. Sample size is indicated by numbers above each bar. Data underlying figure 2 are deposited in the Dryad Digital Repository, doi:10.5061/dryad.s9f7c (Campbell et al. 2015)

Figure 3 Mean $( \pm$ SE) number of nest-sites per branch for the four ant species on $V$. erioloba at Kuzikus Wildlife Reserve. Analysis of variance showed that nest-site density varies significantly $\left(F_{3,211}=3.603, P<0.05\right)$ between ant species (Cataulacus $n=40$, Crematogaster $n=75$, Tapinoma $n=94$ and Tetraponera $n=6$ ). Different letters indicate significant differences $(P<0.001)$ using Tukey HSD test for post hoc comparisons.

Figure A1 Diagrammatic representation of multiple species co-occupancy on V. erioloba trees at Kuzikus Wildlife Reserve, Namibia. Small circles indicate the presence of nonswollen thorns, large circles indicate swollen thorns, i.e domatia, that are suitable potential nest sites for ants. Occupants of domatia are indicated by the pattern within the large circle as follows $;$ empty $=$ no occupant, black $=$ Tapinoma, dots $=$ Crematogaster, vertical stripe $=$ Cataulacus, horizontal stripe $=$ Tetraponera 


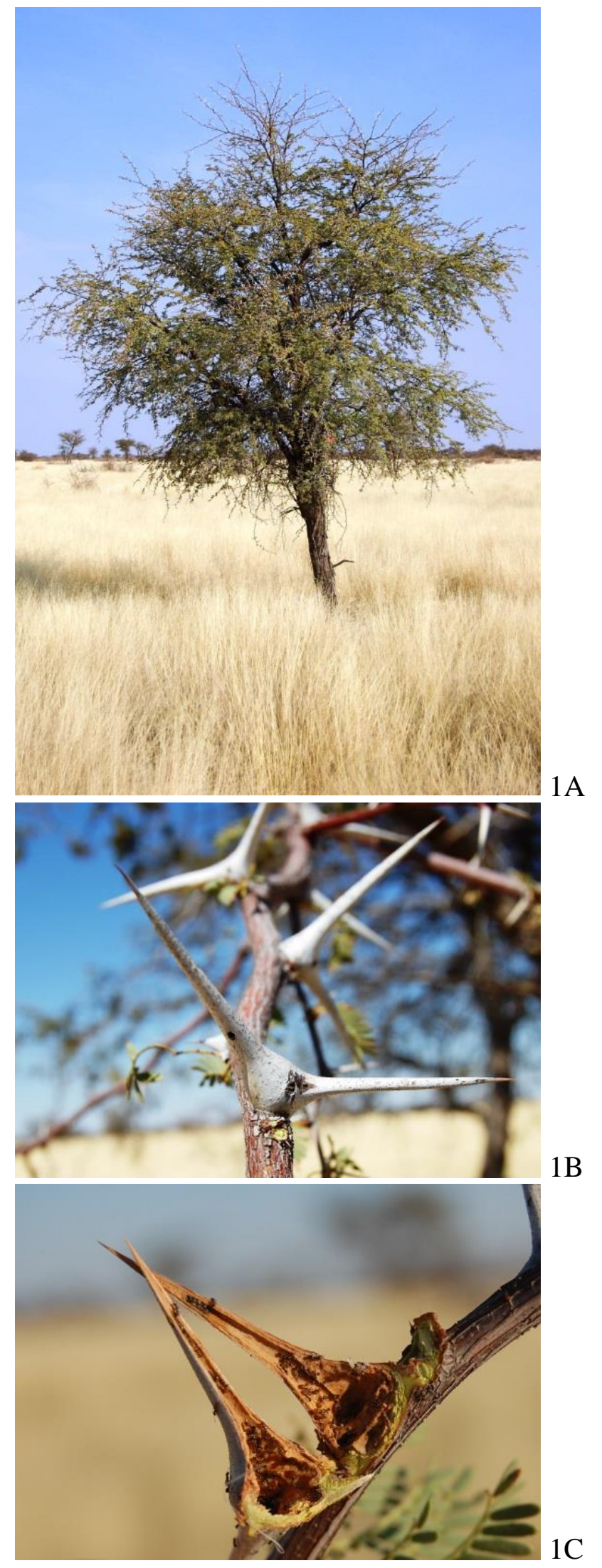


Figure 2

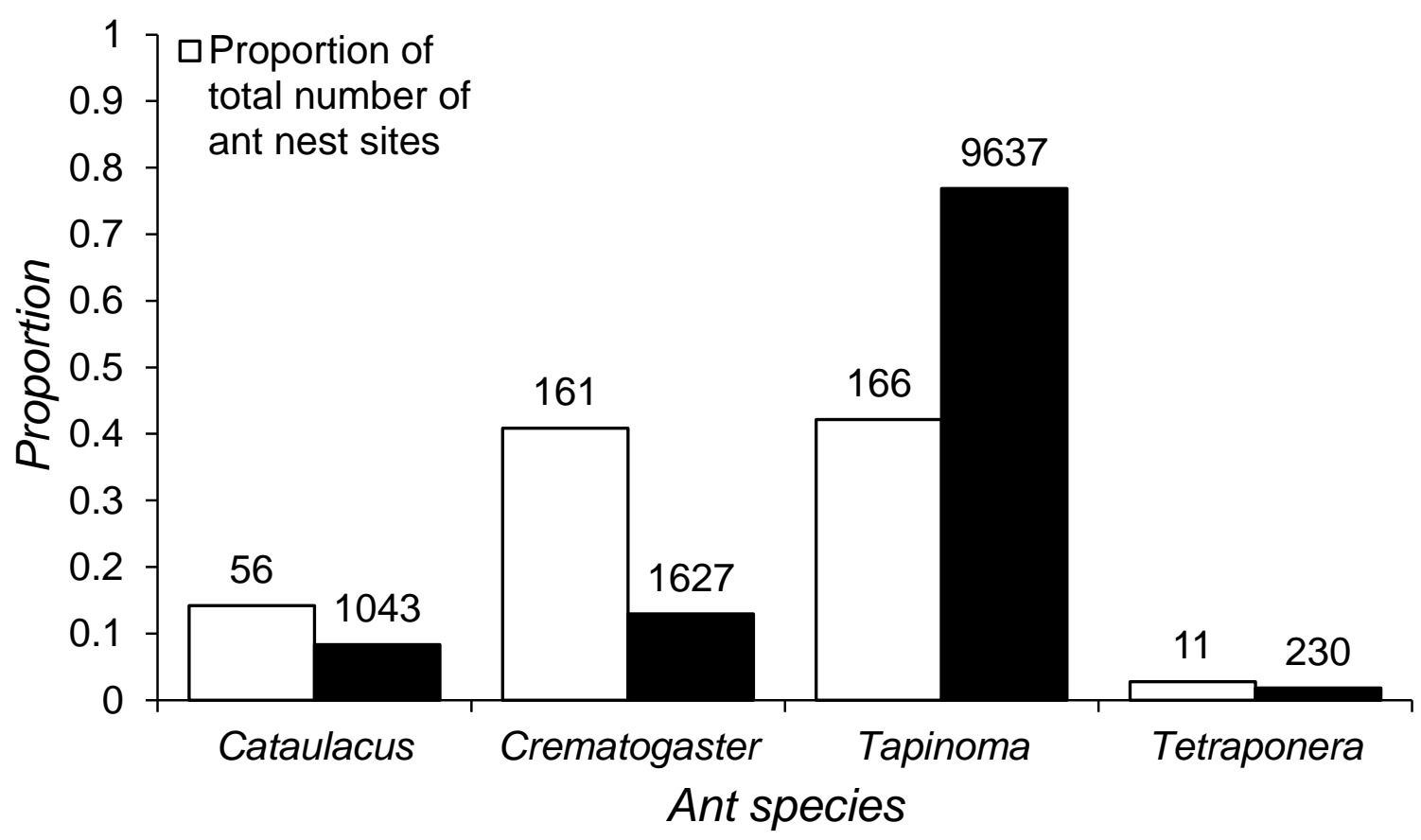


Figure 3

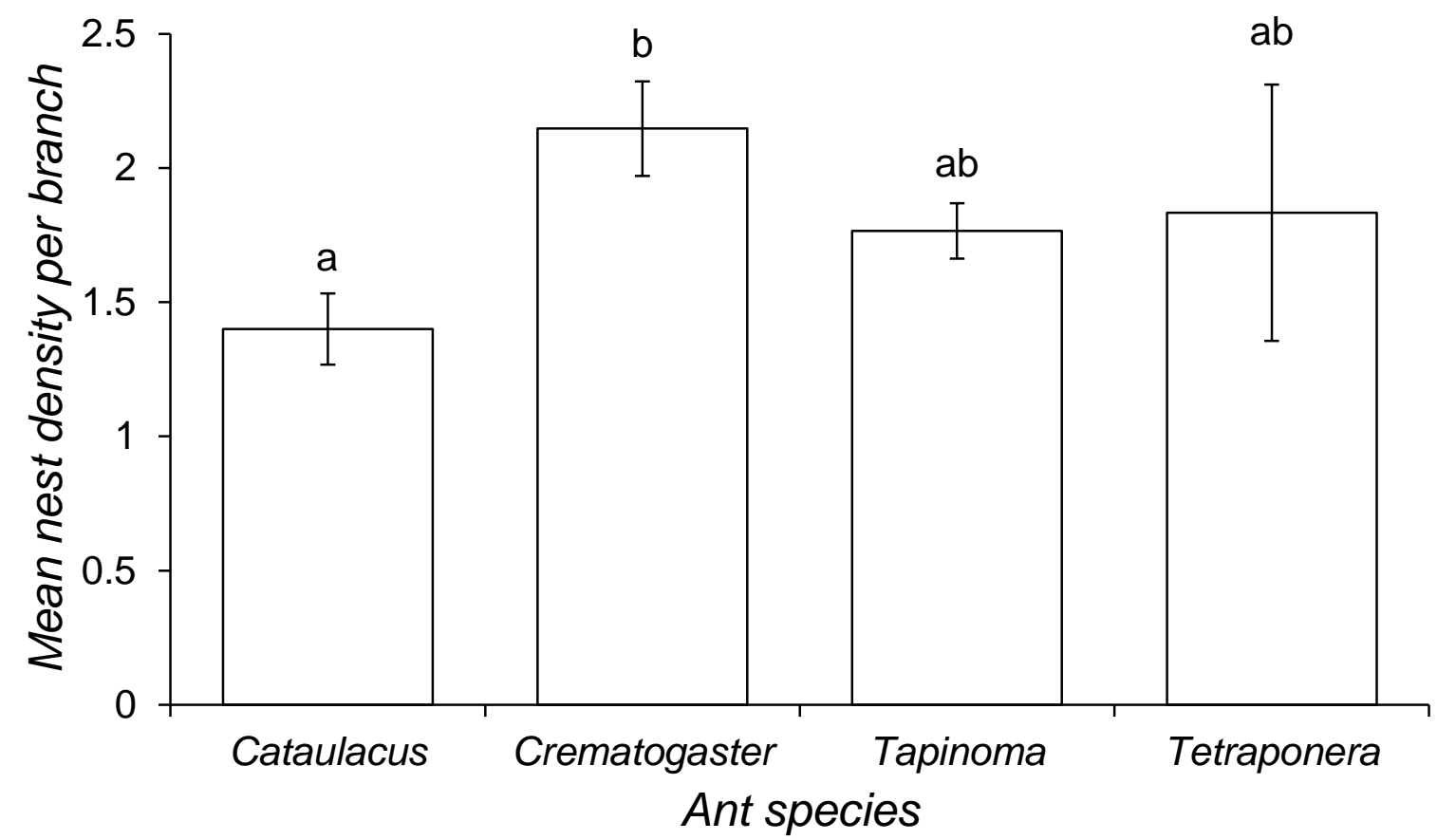

